\title{
CARES: Carbonaceous Aerosol and Radiative Effects Study Science Plan
}

May 2010

RA Zaveri

Principal Investigator

WJ Shaw

DJ Cziczo 


\section{DISCLAIMER}

This report was prepared as an account of work sponsored by the U.S. Government. Neither the United States nor any agency thereof, nor any of their employees, makes any warranty, express or implied, or assumes any legal liability or responsibility for the accuracy, completeness, or usefulness of any information, apparatus, product, or process disclosed, or represents that its use would not infringe privately owned rights. Reference herein to any specific commercial product, process, or service by trade name, trademark, manufacturer, or otherwise, does not necessarily constitute or imply its endorsement, recommendation, or favoring by the U.S. Government or any agency thereof. The views and opinions of authors expressed herein do not necessarily state or reflect those of the U.S. Government or any agency thereof. 


\section{CARES: Carbonaceous Aerosol and Radiative Effects Study Science Plan}

RA Zaveri, Pacific Northwest National Laboratory

WJ Shaw, Pacific Northwest National Laboratory

DJ Cziczo, Pacific Northwest National Laboratory

May 2010

Work supported by the U.S. Department of Energy,

Office of Science, Office of Biological and Environmental Research 


\section{Contents}

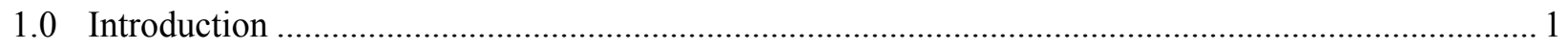

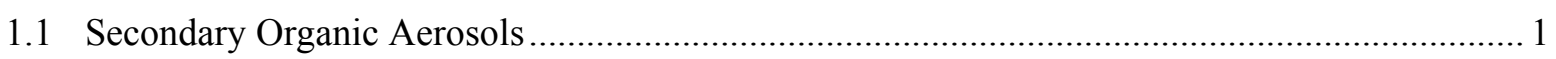

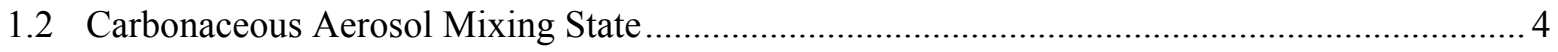

1.3 Carbonaceous Aerosol Optical Properties........................................................................... 7

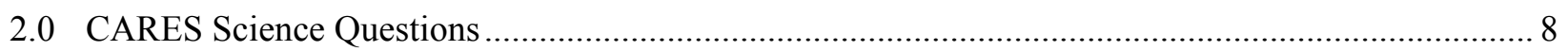

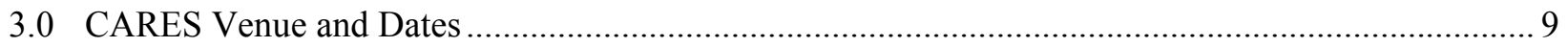

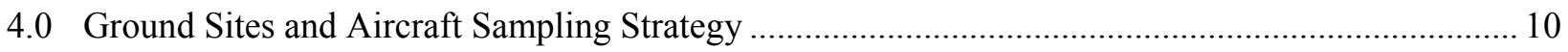

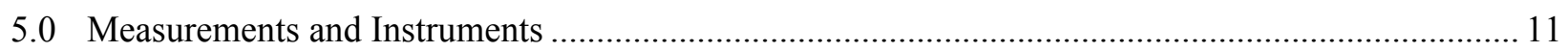

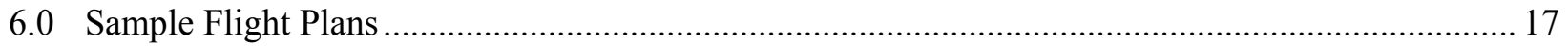

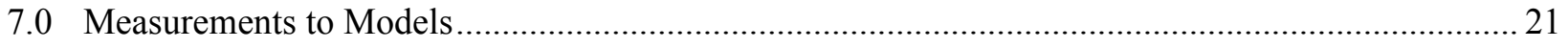

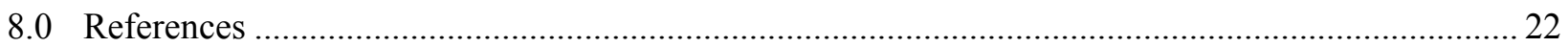




\section{Figures}

1 Strong correlation observed between SOA and odd oxygen in the Mexico City urban area during MILAGRO 2006.

2 SOA found to be the dominant fraction of the total organic aerosol mass observed at a suburban site in Mexico City during MILAGRO 2006.

3 Predicted distribution of BC-specific absorption and critical supersaturation as a function of size after 12 hours of processing in an idealized urban plume scenario ......................................... 5

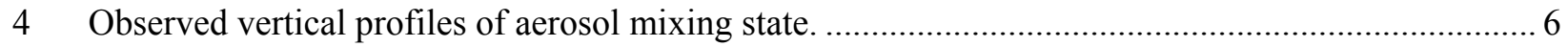

5 Observed single scattering albedo as a function of wavelength in Mexico City during the

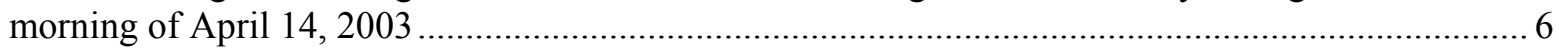

6 VOC emissions in the Central Valley: (A) anthropogenic, and (B) biogenic ................................. 10

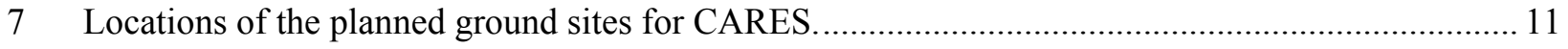

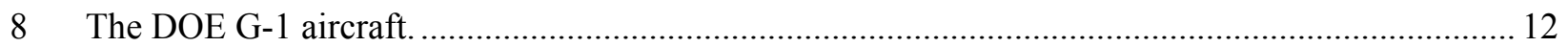

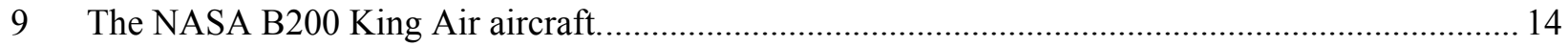

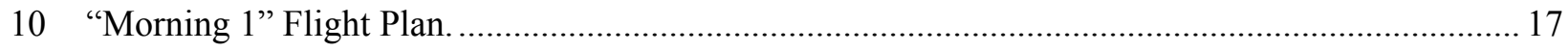

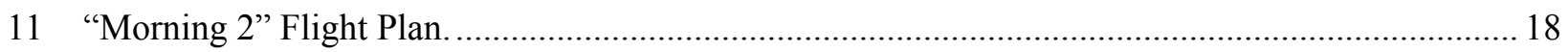

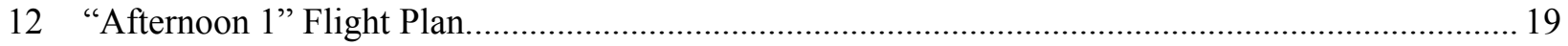

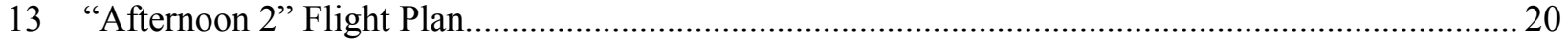

\section{Tables}

1 List of Planned Measurements and Instruments onboard the DOE G-1 Aircraft............................ 13

2 List of Planned Measurements and Instruments onboard the NASA B-200 King Air Aircraft. ........ 14

3 List of Planned Measurements and Instruments at T0 ............................................................... 15

4 List of Planned Measurements and Instruments at T1 ............................................................... 16 


\subsection{Introduction}

One of the goals of the U.S. Department of Energy's (DOE) Atmospheric System Research (ASR) is to develop, evaluate, and improve models and parameterizations of various aerosol processes and properties, so that they can be reliably used in regional and global models to assess the direct and indirect aerosol radiative effects on the climate system. Furthermore, particular emphasis is placed on improving the scientific understanding of the role of anthropogenic emissions on aerosol formation and how they interact with natural aerosols and age over a range of meteorological and chemical environments via an integrated approach to field, laboratory, and modeling studies.

Field observations show that tropospheric aerosol particles can be composed of a wide variety of compounds, including sulfate, nitrate, ammonium, sea salt, crustal species from soil dust, and carbonaceous materials (Seinfeld and Pandis 1998). Primary carbonaceous aerosols include black carbon (BC) particles (or light-absorbing carbon) mixed with nominally non-absorbing organic compounds that are directly emitted from fossil fuel combustion, cooking, industrial processes, and biomass burning (agricultural burning and natural wildfires). Secondary carbonaceous aerosols, commonly referred to as secondary organic aerosols (SOA), are formed via homogeneous nucleation, condensation, and heterogeneous reactions of myriad photochemical oxidation products from numerous volatile and semivolatile organic compounds of both anthropogenic and biogenic origins. Analyses of ambient aerosols have shown that carbonaceous compounds constitute between $20 \%$ and $90 \%$ of the dry particle mass (Kanakidou et al. 2005, Zhang et al. 2007).

Although some process-level uncertainties and knowledge gaps still exist (e.g., new particle formation, ice nucleation), the formation, evolution, and properties of the key inorganic components of tropospheric aerosols are now relatively well understood and adequately represented in state-of-the-art aerosol models (e.g., Wexler and Seinfeld 1991, Jacobson 2002, Zhang et al. 2004, Zaveri et al. 2008). On the other hand, large uncertainties still exist in the fundamental understanding of the formation, evolution, and climateaffecting properties of the various carbonaceous components of tropospheric aerosols. Consequently, the available aerosol models do not have reliable treatments for the formation and evolution of carbonaceous aerosol mass, size-distribution, and mixing state, let alone the related hygroscopic and optical properties. Some of the key uncertainties that motivate the CARES field campaign are briefly discussed below.

\subsection{Secondary Organic Aerosols}

Several studies have shown that current models significantly underpredict SOA formation in the ambient urban atmosphere as well as in the upper troposphere (de Gouw et al. 2005, Heald et al. 2005, Johnson et al. 2006, Volkamer et al. 2006). There are also indications that most SOA forms rapidly in urban plumes within the first 24 hours (and not later) and perhaps even in the first 12 hours (Volkamer et al. 2006, Kleinman et al. 2008, de Gouw et al. 2008). Recently, Robinson et al. (2007) suggested that some SOA mass at urban to regional scales may be from volatilization of high molecular weight semi-volatile organic compounds (SVOC) from diesel exhaust primary organic aerosols (POA), followed by condensation of their oxidation products. This hypothesis is consistent with the large number of low concentration SVOCs observed in urban areas (Lewis et al. 2000). More recently, Herndon et al. (2008) found a strong correlation between the observed SOA and odd oxygen $\left(\mathrm{O}_{3}+\mathrm{NO}_{2}\right)$ in the Mexico City urban area (Figure 1). Zaveri et al. (2010a) also showed that SOA was the dominant fraction of the total 
organic aerosol mass in the afternoon at a suburban site north of Mexico City, while urban POA and biomass burning organic aerosol (BBOA) were relatively small (Figure 2). In a related study, de Gouw et al. (2009) demonstrated that the growth of SOA at this site could not be explained in terms of the measured VOC precursors and their chamber-based particulate mass yields and formation kinetics. While these studies point to a potentially significant role of SVOCs in SOA formation, a definitive evaluation of this hypothesis has not yet been possible due to lack of SVOC measurements in conjunction with comprehensive gas-phase VOC and organic aerosol mass and composition measurements in an evolving urban plume.

\section{Pollutants and Photochemistry in the Mexico City Metropolitan Area}

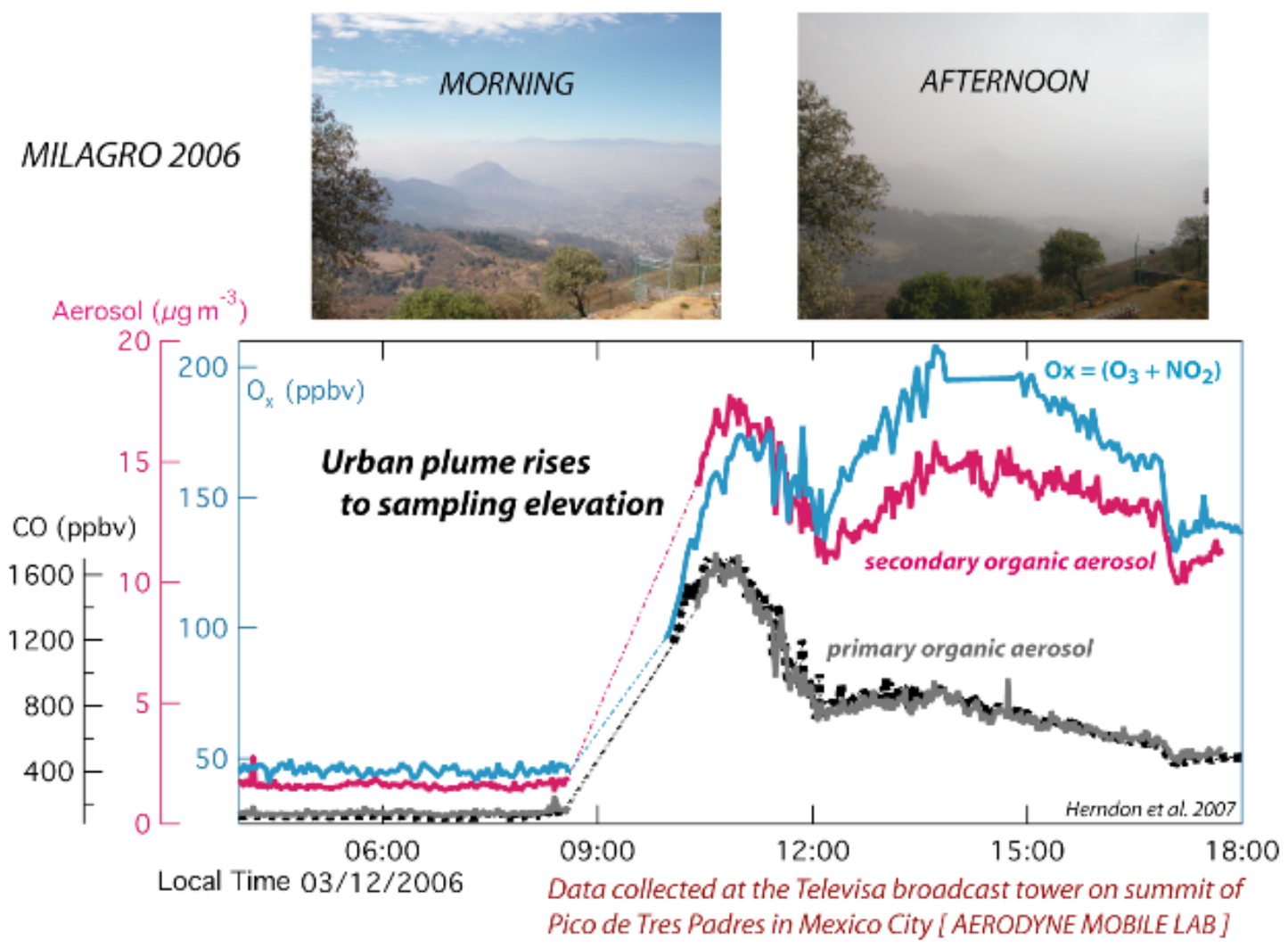

Figure 1. Strong correlation observed between $\mathrm{SOA}$ and odd oxygen $\left(\mathrm{O}_{3}+\mathrm{NO}_{2}\right)$ in the Mexico City urban area during MILAGRO 2006 (from Herndon et al. 2008). The "Aerosol” Y-axis (pink) corresponds to both the SOA and POA time traces. 


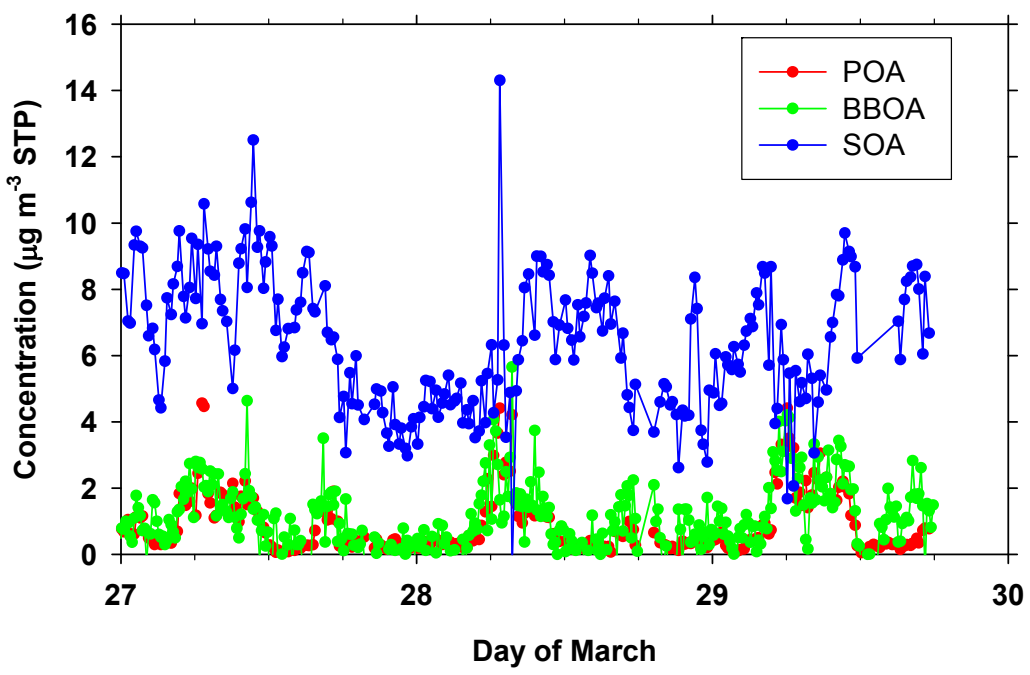

Figure 2. SOA found to be the dominant fraction of the total organic aerosol mass observed at a suburban site in Mexico City during MILAGRO 2006 (Zaveri et al. 2010a).

Weber et al. (2007) found that fine-particle water soluble organic carbon (WSOC) mass in aged urban plumes in the eastern United States was highly correlated with anthropogenic emissions. However, the carbon isotope $\left({ }^{14} \mathrm{C}\right)$ analysis on the WSOC samples indicated that roughly $70-80 \%$ of the carbon was of biogenic (modern) origin. The available semi-empirical SOA models based on smog chamber experiments (e.g., Odum et al. 1996, 1997) predict increased SOA yields from biogenic precursors with an increase in the pre-existing primary organic aerosol mass from urban sources (Kanakidou et al. 2000, Chung and Seinfeld 2002, Tsigaridis et al. 2006). However, a recent smog chamber study by Song and Zaveri et al. (2007) showed that the presence of pre-existing hydrophobic primary organic aerosols, such as lubricating oil aerosol, may not enhance the SOA yields. This is presumably because hydrophobic POA and water soluble SOA do not form a well-mixed solution as is typically assumed in most semiempirical SOA models, including the recent "volatility basis set" model of Donahue et al. (2006). On the other hand, the presence of non-volatile or low volatility SOA species, such as those that can form from oxidation of SVOCs, may facilitate absorption of additional semi-volatile and volatile SOA species in an urban plume.

Many recent laboratory studies have implicated heterogeneous chemistry of semi-volatile and volatile organic vapors within aqueous inorganic aerosols as a potential route for SOA formation from biogenic precursors (Jang et al. 2003; Kroll et al. 2005; Liggio et al. 2005, 2007; Limbeck et al. 2003). While these results suggest that anthropogenic emissions and/or oxidants may somehow enhance the amount of SOA mass formed from biogenic precursors, the actual mechanism remains a mystery.

In summary, there are presently at least two major issues that need to be addressed before we can reliably model (or parameterize) SOA formation in regional and global climate models: (1) the observed more rapid and higher SOA formation yields than expected from the measured precursors and available SOA models, and (2) the unexplained correlation observed between high mass fraction SOA of biogenic origin and urban emissions. While the previously unmeasured SVOCs and some of the proposed mechanisms and pathways could potentially help explain some of the observations, carefully designed field experiments and well-constrained modeling studies are needed to systematically investigate their role in SOA formation. 
In the CARES 2010 campaign, we have selected a venue (described in more detail in Section 3.1) where we will be able to observe the growth of SOA in a predominantly urban plume as it evolves during the first 6 to 8 hours before mixing with biogenic precursors in the late afternoon. We will directly measure several primary SVOCs (long chain alkanes and aromatics), VOCs, selected oxidation products, and organic aerosol mass and composition. These results will be placed in the context of measurements of other ancillary trace gases, particle size distributions, ensemble (bulk) aerosol optical and cloud condensation nuclei $(\mathrm{CCN})$ activation properties, and meteorological measurements in the urban plume as a function of downwind distance/processing time before and after it mixes with the biogenic emissions. The comprehensive data set will then be used to effectively initialize, constrain, and evaluate comprehensive SOA aerosol model(s) being developed by ASR investigators (and elsewhere) within Lagrangian and Eulerian frameworks to systematically investigate the roles of different urban SVOCs and VOCs, biogenic VOCs, and the different possible pathways in SOA formation.

\subsection{Carbonaceous Aerosol Mixing State}

Primary carbonaceous aerosols of different types are externally mixed when emitted and differ in optical and hygroscopic properties depending on the source. Upon interacting with semi-volatile gases in the atmosphere via condensation (and evaporation) and with other particles of similar or different compositions via coagulation, these particles undergo changes in size, morphology (shape), and chemical composition and gradually become internally mixed to varying degrees. This process is called evolution or "aging" of aerosols. The radiative properties, CCN activation super-saturations, and chemical reactivities of fresh and aged aerosol particles can differ significantly. Several modeling studies have examined the role of coagulation in transforming externally mixed soot aerosols into internal mixtures (Strom et al. 1992, Jacobson et al. 1994, Fassi-Fihri et al. 1997). Kleeman et al. (1997) developed a Lagrangian air quality model in which the aerosol particle populations are represented as source-oriented external mixtures which can evolve differently due to condensation processes while coagulation was neglected. Jacobson (2002) used an aerosol model that treats aging of soot due to both coagulation and condensation using 18 different particle size distributions (including 3 for aged soot with varying shell fractions) spread over 17 size bins and concluded that internal mixing occurs within $\sim 12$ hours.

More recently, Riemer et al. (2008) developed a stochastic particle-resolved aerosol box-model, PartMCMOSAIC, that explicitly resolves the composition and mixing state of individual particles in a given population of different types of aerosols. They applied it to an idealized urban plume scenario based on Los Angeles emissions and found that $\mathrm{BC}$ particles have a wide range of mixing states after 12 to 24 hours of processing. Evolution of aerosol mixing state was shown to be a highly complex phenomenon, which strongly depended on the concentration and composition of the emitted particles, gas-phase photochemical oxidation rates, dynamic mass transfer of condensable trace gases to particles of different sizes and compositions, coagulation rates, temperature, relative humidity, dilution with background air, and processing time since emission. In a follow-on study, Zaveri et al. (2010b) investigated the evolution of aerosol optical, hygroscopic, and cloud activation properties with the particle-resolved aerosol model and found that these properties are highly sensitive to the aerosol mixing state after 12 to 24 hours of processing. As an example, Figure 3 shows the predicted distributions of BC-specific absorption and critical supersaturation as a function of size after 12 hours of processing. Each dot is an individual model particle, colored according to its predicted $\mathrm{BC}$ dry mass fraction. It can be readily seen that particles of the same size have widely different black carbon mass fraction, BC-specific absorption at $500 \mathrm{~nm}$ wavelength, and critical supersaturation. 

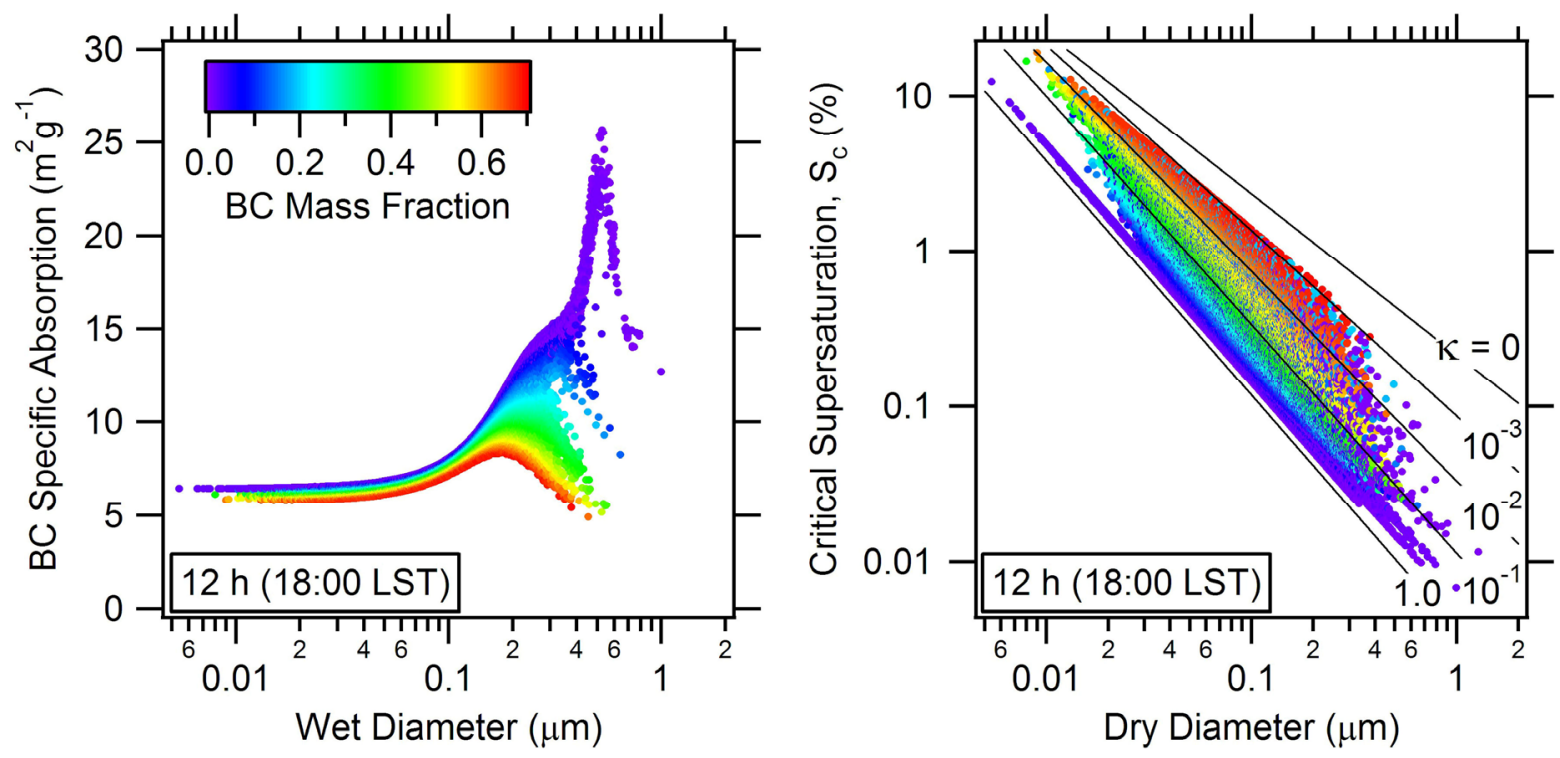

Figure 3. Predicted distribution of BC-specific absorption and critical supersaturation as a function of size after 12 hours of processing in an idealized urban plume scenario. The results are obtained with the particle-resolved aerosol model PartMC-MOSAIC. Each dot represents an individual particle, which is colored according to its predicted $\mathrm{BC}$ dry mass fraction (Zaveri et al., 2010b).

Single-particle aerosol composition measurements (e.g., PALMS, ATOFMS, SPLAT) have been used in field studies for more than 10 years (Murphy and Thomson 1997, Hughes et al. 2000, Moffet and Prather 2005, Spencer and Prather 2006, Zelenyuk et al. 2006), and it is now also possible to obtain scattering cross-sections of individual particles as a function of particle size and mixing state (Moffet et al. 2008). Addition of angular information to the single-particle measurement with the ATOFMS in the near future will provide the scattering phase function and single-scattering albedo as a function of aerosol mixing state. These new developments on both the single-particle modeling and measurement fronts will allow us to significantly advance our understanding of the evolution of aerosol mixing state and its effect on radiative forcing. Of particular interest for climate forcing is the variation of aerosol mixing state as a function of altitude. In the first aircraft studies with a newly developed aircraft single particle mass spectrometer, ATOFMS, the mixing state of aerosols (dust, soot, OC, sea salt, soot) were measured as a function of altitude. Figure 4 shows the first real-time measurements of the mixing state of soot, providing insight into how soot evolves as a function of altitude. At low altitude, soot is mixed with secondary species such as nitrate, but with increasing altitude, fresh fractal soot particles mixed with sulfate become dominant. The size and optical properties of these same soot particles were also measured in the ATOFMS.

We will use such vertical profiles of single particle measurements in a relatively well-defined urban plume at increasing processing times to effectively constrain and evaluate our particle-resolved aerosol model as well as the 3-D WRF-chem/MOSAIC model that resolves mixing states with a sectional approach. The proposed CARES 2010 campaign will provide the ideal conditions to observe and model such evolution processes and better understand how optical properties, hygroscopicity, and CCN activity change as the particles evolve. 


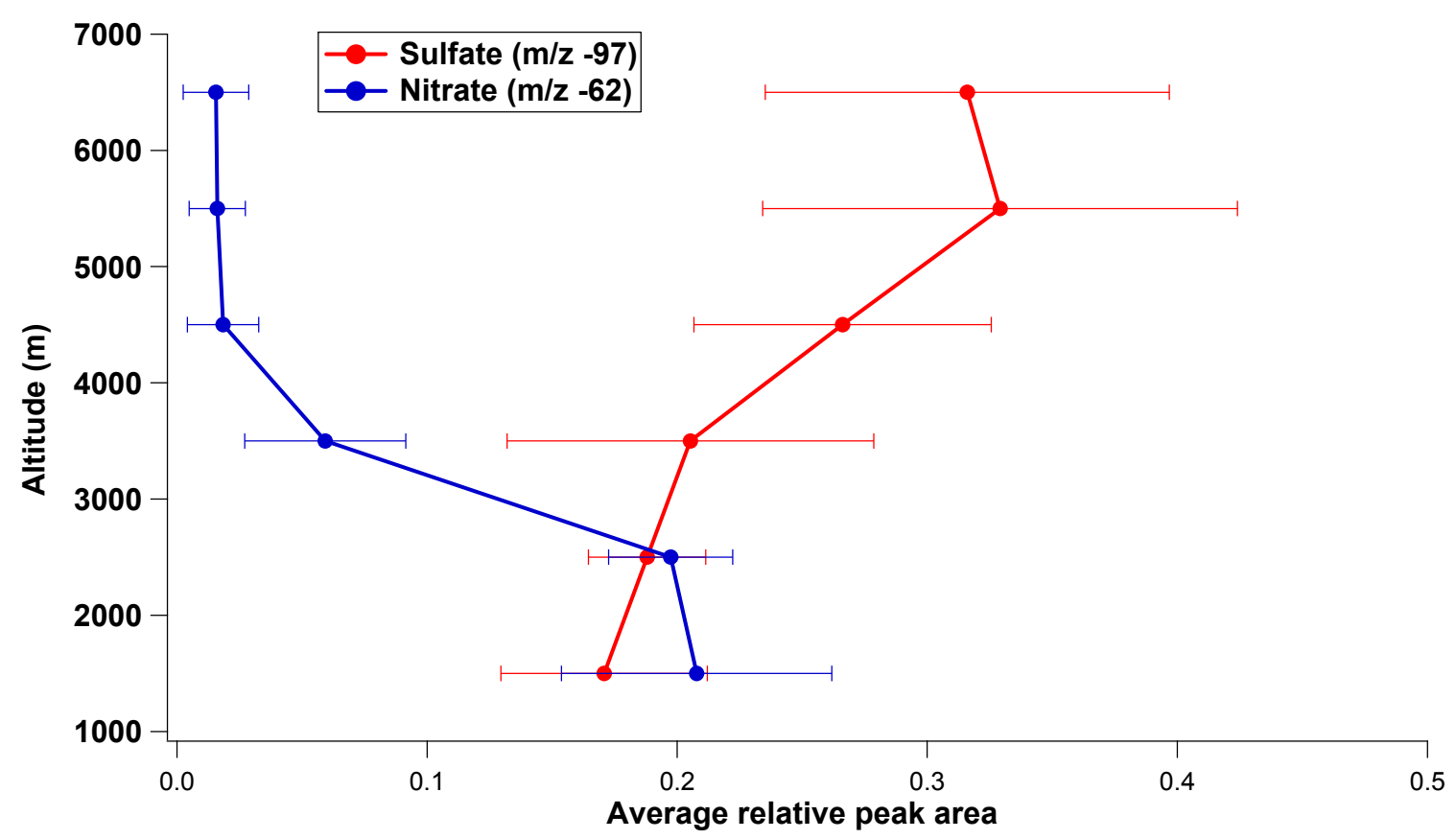

Figure 4. Observed vertical profiles of aerosol mixing state (personal communication, Dr. K.A. Prather).

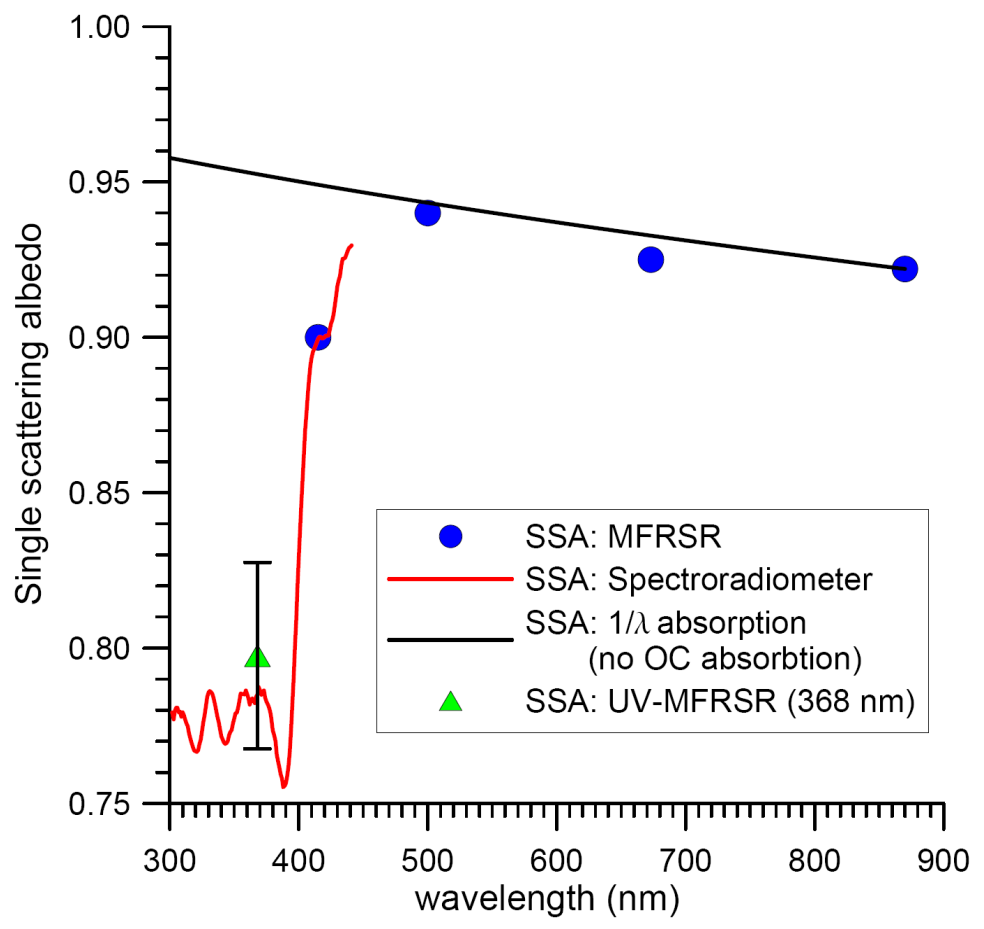

Figure 5. Observed single scattering albedo (SSA) as a function of wavelength in Mexico City during the morning of April 14, 2003 (Barnard et al. 2008). The black line is the SSA, extrapolated from $870 \mathrm{~nm}$ to lower wavelengths, if the absorption follows the $\lambda^{-1}$ dependence. 


\subsection{Carbonaceous Aerosol Optical Properties}

Not only does the chemical evolution of carbonaceous aerosols present an ongoing challenge, but the fundamental optical properties of these aerosols are fraught with uncertainty as well. Analysis of aerosol and radiation measurements made during the MCMA-2003 and MILAGRO 2006 field campaigns has provided evidence of enhanced near-UV absorption by organic aerosols (Barnard et al. 2008). This enhanced absorption is illustrated in Figure 5, which shows the single-scattering albedo (SSA) plotted versus wavelength $(\lambda)$ during the morning of April 14, 2003 in Mexico City. Between $500 \mathrm{~nm}$ and 900 $\mathrm{nm}$ the trend of SSA with wavelength is consistent with the $\lambda^{-1}$ absorption dependence predicted by the Mie theory for BC (Bergstrom et al. 2002, Bond and Bergstrom 2006), but for $\lambda$ less than $500 \mathrm{~nm}$, the absorption increases dramatically, and the $\lambda^{-1}$ rule completely breaks down. This enhanced absorption in the UV could not be explained by $\mathrm{BC}$, dust, or gases, and hence it was suggested to stem from the organic aerosol (OA).

Although the MILAGRO and MCMA-2003 field campaigns were extremely useful for recognizing the potential for OA absorption, these campaigns were not specifically designed to study this phenomenon, with the result that full closure was not possible. Additional field measurements are necessary to investigate OA absorption and scattering in both the near-UV and visible spectral regions. For example, recent evidence (Lack et al. 2008) suggests that absorption measurements from filter-based instruments (e.g., PSAP) are highly suspect in the presence of OA. Photoacoustic and other newer technologies bypass the filter problem and have been useful for measuring absorption coefficients in the visible region, but the spectral range of these instruments must be pushed to lower wavelengths (Lewis et al. 2008) to specifically look at the OA absorption issue.

These newer techniques (including cavity ring-down aerosol extinction instruments) will form a critical part of resolving a second important issue: to what extent does OA absorb (and scatter) in the visible spectrum? The studies of Kirchstetter et al. (2004) and Sun et al. (2007) have suggested the possibility that the mass absorption coefficient at $550 \mathrm{~nm}$ could be about $1 \mathrm{~m}^{2} / \mathrm{g}$. Although this is significantly less than the $7.5 \mathrm{~m}^{2} / \mathrm{g}$ figure associated with uncoated BC (Bond and Bergstrom 2006), OA absorption in the visible region could rival that of $\mathrm{BC}$ if there is enough OA present (Clarke et al. 2007). Thus, we need to find out if and when organic species contribute to the atmospheric warming, above and beyond the contribution of black carbon.

We have designed the CARES field campaign motivated by the scientific issues described above and in anticipation of the new/improved, physically based SOA mechanisms, BC aging models, and aerosol optical and hygroscopicity models that will need to be validated under a range of ambient atmospheric conditions. Also, new/improved instruments will be available in 2010 that were not deployed in the past. The primary objectives of this "clear-air" field campaign are to investigate the evolution and aging of carbonaceous aerosols and their climate-affecting properties in the urban plume of Sacramento, California, a mid-size, mid-latitude city that is located upwind of a biogenic VOC emission region. Our basic observational strategy is to make comprehensive gas, aerosol, and meteorological measurements upwind, within, and downwind of the urban area with the DOE G-1 aircraft and at strategically located ground sites so as to study the evolution of urban aerosols as they age and mix with biogenic SOA precursors. The NASA B-200 aircraft, equipped with the High Spectral Resolution Lidar (HSRL), digital camera, and the Research Scanning Polarimeter (RSP), will be flown in coordination with the G-1 to characterize the vertical and horizontal distribution of aerosols and aerosol optical properties, and to 
provide the vertical context for the G-1 and ground in situ measurements. The selected venue is based on a number of scientific, logistical, and collaborative research considerations outlined in Section 3.

\subsection{CARES Science Questions}

As discussed above, there are many mechanistic and process-level uncertainties or knowledge gaps in the treatment of carbonaceous aerosols in models that must be addressed using a systematic and integrated approach built around both laboratory and field studies. However, evaluation and validation of the next generation of SOA and optical properties models will be particularly challenging. For instance, a good agreement between the predicted total SOA mass and the inferred SOA mass from observations will be necessary but not sufficient. Additional checks and measures will be required to convince ourselves that the new models are giving the right answers for the right reasons, and that they have reliable sensitivities to the key model variables/parameters such as precursor gases, processing time, pre-existing aerosol composition, temperature, $\mathrm{RH}$, dilution, etc. Similar issues exist for $\mathrm{BC}$ aging, $\mathrm{CCN}$ activation, newparticle formation, and aerosol optics modules.

With these ideas in mind, a list of key process-level questions and knowledge gaps can be grouped under three themes:

- Secondary Organic Aerosols

1. What are the SVOC concentrations in an evolving urban plume, how do they scale with VOC and $\mathrm{CO}$ concentrations, and how are these aerosol precursor gases correlated with organic aerosol number and mass concentrations?

2. What are the chemical composition, volatility spectrum, and hygroscopicity of the SOA, and how do they evolve as a function of atmospheric processing time and photochemical age? What is the oligomeric fraction in the observed SOA, and does it correlate with particle acidity?

3. Can we see a temperature and/or relative humidity dependence of SOA within vertical profile measurements in a well-mixed boundary layer?

4. Using carbon isotope analyses, can we separate the observed SOA in the aged urban plume into anthropogenic and biogenic fractions? Can we see enhanced biogenic SOA mass in the urban plume compared to outside of the urban plume?

- Aerosol Mixing State

1. What is the distribution of $\mathrm{BC}$ mass fraction (BC mixing state) as a function of particle size in fresh and aged urban plumes? How rapidly do POA, BC, SOA, and inorganics become internally mixed?

2. How does $\mathrm{BC}$ mixing state (and the overall aerosol mixing state) change as a function of altitude?

3. What are the relative roles of condensation and coagulation processes in shaping the aerosol composition and size distribution?

4. Can we quantify the effects of aerosol mixing state on the ensemble aerosol optical properties, hygroscopicity, and $\mathrm{CCN}$ activity? 
- Aerosol Optical Properties

1. Is the enhanced near-UV absorption observed during MILAGRO important in other urban and biogenic locations? Does OA absorption extend into the visible part of the spectrum?

2. What is the source of this enhanced absorption? Is it due to urban POA, biomass burning organic aerosols, or secondary species (SOA, nitrate, sulfate) condensing on pre-existing particle seeds, or a combination of sources?

3. Which compounds or particle types, in particular, have the strongest radiative impacts, and can these be related to specific emission sources or atmospheric processes?

4. What is the role of changes in mixing state and/or particle morphology on the enhanced absorption in the near-UV?

While not all the questions listed above will be fully resolved in the CARES 2010 campaign, the goal is to address as many as possible.

\subsection{CARES Venue and Dates}

The CARES campaign will be centered on Sacramento, California, from June 2 through June 28, 2010. Sacramento is located in California's expansive Central Valley and is the seventh most populous city in California with a 2007 estimated population of 467,343. The four-county Sacramento Metropolitan Area is the largest in the Central Valley, with a population of 2.1 million. Figure 6 shows the geographic distribution of anthropogenic and biogenic emissions in central California. While transport processes over the entire Central Valley can be complex (Bao et al. 2008), the transport of the Sacramento urban plume during the summer is controlled by extremely consistent, terrain-driven upslope winds that draw polluted air to the northeast over oak and pine trees in the Blodgett Forest area in the Sierra Nevada Mountains by late afternoon. The Sacramento-Blodgett Forest corridor effectively serves as a mesoscale $(\sim 100 \mathrm{~km})$ daytime flow reactor where the daily evolution of the Sacramento urban plume can be characterized as a Lagrangian air parcel transported from the urban core into the sparsely populated Sierra Nevada Mountains (Dillon et al. 2002, Murphy et al. 2007). The Sacramento-Blodgett Forest corridor is therefore ideally suited for deploying multiple ground sites and aircraft sampling within and outside of the urban plume and the biogenic VOC-dominated areas. A number of ozone formation studies recently conducted in this region (Dillon et al. 2002; Murphy et al. 2006, 2007; Steiner et al. 2007) and the (summer 2007 and 2008) Biosphere Effects on Aerosols and Photochemistry Experiment (BEARPEX) at the Blodgett Forest site provide an excellent foundation for the comprehensive CARES campaign in 2010. While the trace gas and aerosol data at the Blodgett Forest site show a weak but distinct signal of the Sacramento urban plume in the late afternoon, this signal is expected to be relatively stronger in the region between Granite Bay and Blodgett Forest where the pollution is expected to mix with biogenic emissions.

Moreover, the Central Valley location of CARES will allow us to take advantage of planned agricultural fires around Sacramento and possibly natural wildfires in the vicinity to study the evolution and properties of biomass burning carbonaceous aerosols. 


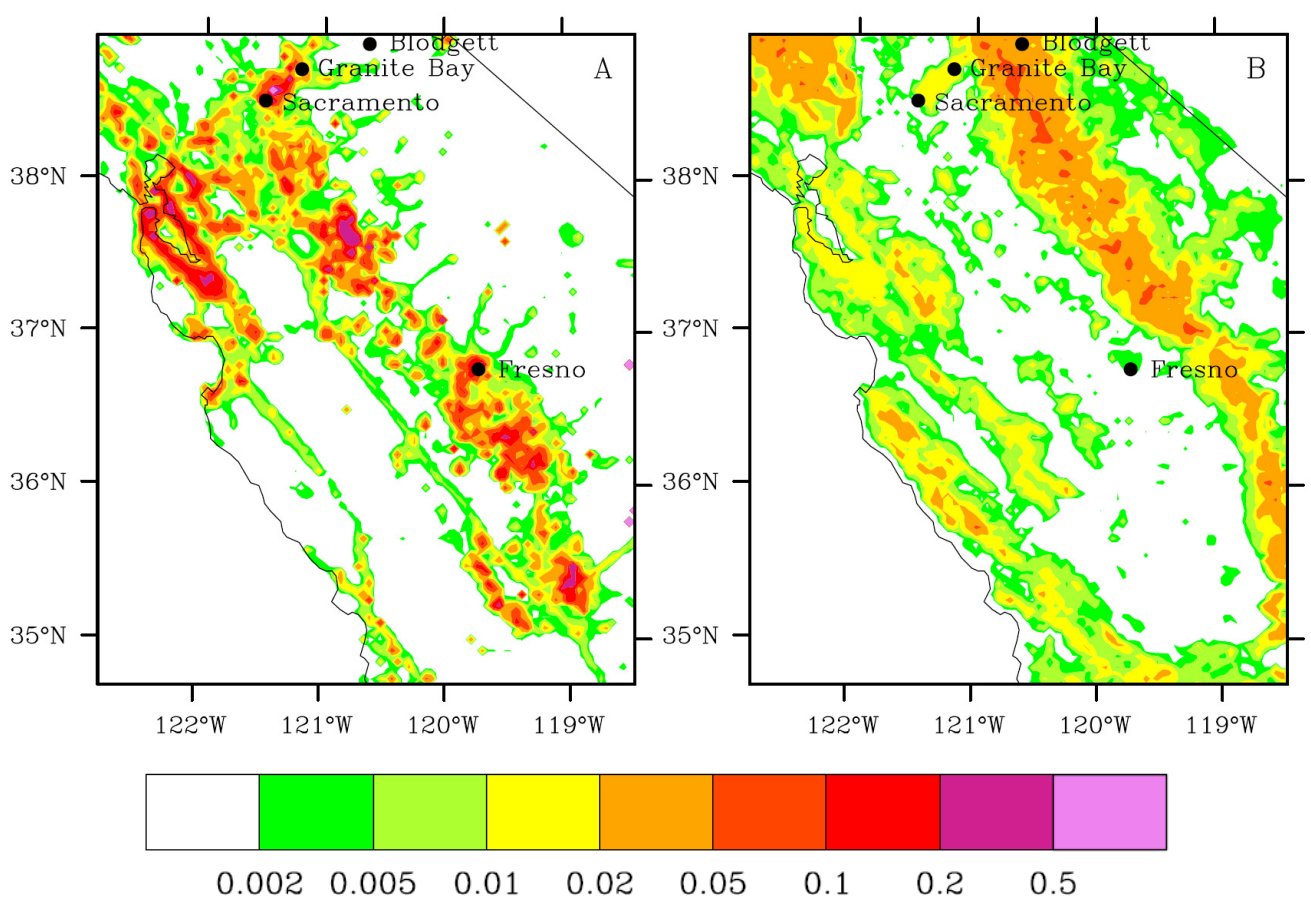

Figure 6. VOC emissions in the Central Valley $\left(\mathrm{mol} \mathrm{s}^{-1}\right)$ : (A) anthropogenic, and (B) biogenic (Steiner et al. 2007).

\subsection{Ground Sites and Aircraft Sampling Strategy}

Figure 7 shows the locations of the two ground sites planned for CARES. The "T0" site is located within the Sacramento urban source area (on the campus of American River College), which is about $14 \mathrm{~km}$ to the northeast of the Sacramento downtown area. The "T1" site is located in the downwind area about 40 $\mathrm{km}$ further to the northeast at the K-8 Northside School in Cool, California, situated amidst biogenic (forest) emissions. The aged urban plume typically arrives at this location around mid-afternoon when ozone, and presumably SOA from urban precursors, is at or near its peak concentration. This timing is consistent with the time-scale for rapid SOA growth reported by de Gouw et al. (2008). As mentioned earlier, there are already substantial amounts of trace gas and aerosol data at the Blodgett Forest site, which is located about $20 \mathrm{~km}$ further northeast in the Sierra Mountains. These data show a distinct but rather weak signal of the Sacramento urban plume in the late afternoon, which is another reason why we have decided to place the T1 site at Cool, closer to Sacramento. The T0 and T1 ground sites will thus characterize the diurnal evolution of meteorological variables, trace gases/aerosol precursors, and aerosol composition and properties in freshly polluted and aged urban air, respectively.

The DOE G-1 and NASA B-200 aircraft flight plans involve transects over the ground sites in the morning and again in the afternoon. Both aircraft will also sample upwind of the Sacramento urban area to characterize the in-flow boundary conditions into the region of interest. We envision this as the primary sampling strategy that will be employed for many days so that we can obtain representative information. This and other sample flight plans are presented in more detail in Section 4.2. 
The resulting ground and aircraft data will lend themselves to detailed model analyses and are expected to provide new insights into the chemical and physical processes governing secondary inorganic/organic aerosol formation, $\mathrm{BC}$ mixing state evolution, and their effects on optical and hygroscopic/CCN activation properties.

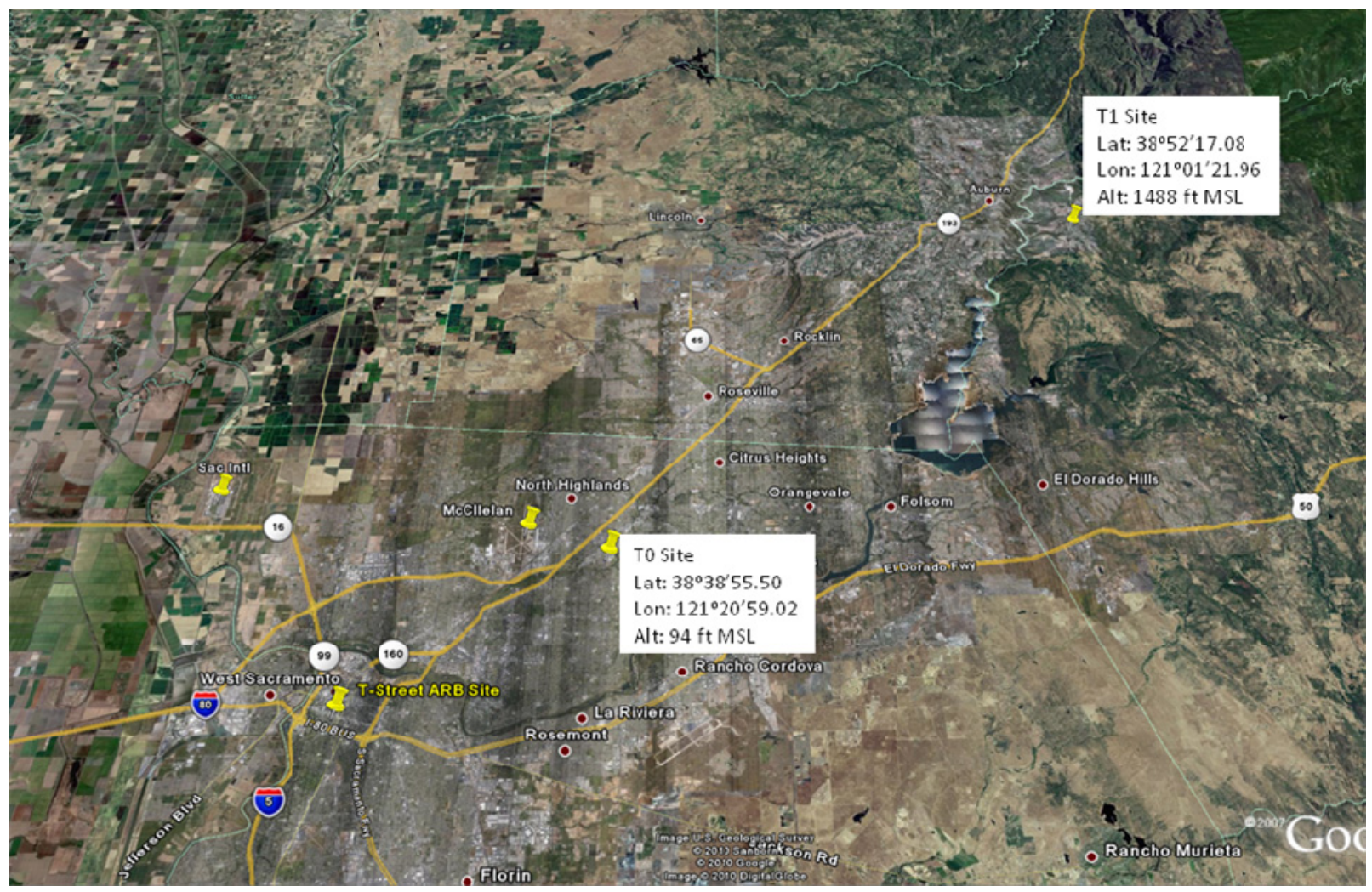

Figure 7. Locations of the planned ground sites (T0 and T1) for CARES.

\subsection{Measurements and Instruments}

Key measurements include aerosol precursor gases, size-resolved particle chemical composition, particle physical properties (morphology, density, optical properties, hygroscopicity, and CCN activation), solar radiation measurements, and meteorological measurements. A nearly identical set of trace gas and aerosol measurements are planned onboard the G-1 aircraft and at each ground site. The complete lists of the measurements and instruments for each site/platform are given below. A Proton-Transfer Reaction Mass Spectrometer (PTR-MS) will be used on the G-1 and at each site to measure mixing ratios of select VOCs, some of which are known SOA precursors. The WSU PTR-MS at T0 will be modified to also characterize the total concentration of semi-volatile long chain alkanes $(>\mathrm{C} 10)$ and heavier monoaromatics associated with diesel exhaust vapor emissions and potential evaporation of diesel particulate matter. In addition, a gas chromatograph ion trap mass spectrometer (GC-ITMS) will be used at $\mathrm{T} 0$ to measure selected $\mathrm{C} 2-\mathrm{C} 10$ VOCs (alkanes, alkenes, aromatics, halocarbons) and oxidation products to determine the extent of air mass photochemical processing. Aerodyne's High Resolution Time of Flight Aerosol Mass Spectrometer (HR-ToF-AMS) will be used on the G-1 aircraft and at each ground site to measure aerosol composition. The ground site units will be coupled to a thermal denuder to 
characterize the volatility of organic aerosols. Particle-In-Liquid Sampler (PILS) with autosampler will be deployed on the G-1 and at each ground site to measure water soluble aerosol species. The NASA B-200 aircraft will deploy a High Spectral Resolution Lidar (HSRL) that measures backscatter ratio, backscatter and extinction coefficients, and depolarization. It will also carry a Research Scanning Polarimeter (RSP) that measures aerosol optical depth.

Significant instrument development has recently occurred, and this project will exploit many advanced techniques as well. For example, several new instruments have become available that characterize the chemical and optical properties of black carbon particles. Several of these instruments participated in the recent DOE-funded black carbon instrument intercomparison project, the Boston College-Aerodyne Soot Project 2, focused on characterizing coated black carbon particles. Intracavity laser instruments, such as the DMT Single Particle Soot Photometer (SP2), are providing single particle and ensemble black carbon mass loading measurements with information on the amount and chemical composition of the particles' coatings and cores. The combination of these new instruments with the single particle mass spectrometers (ATOFMS, SPLAT II, and PALMS) and single particle microscopy and microspectroscopic studies on TRAC samples will enable better characterization of the mixing state, size, chemical composition, and transformations of black carbon containing particles. Coupling these measurements with real-time optical instruments such as the cavity ring-down and the multi-wavelength photoacoustic instruments will provide direct chemical-related information on the absorption, scattering, and extinction characteristics of urban particulate soot emissions. The combination of optical (especially UV) and mass-based (incandescence and mass spectrometry) black carbon instruments will enable the measurement of massspecific absorption coefficients of soot particles and identify potential light-absorbing organic compounds in urban and biomass burning plumes.

The CARES campaign will deploy several new instruments purchased through the American Recovery and Reinvestment Act of 2009 (ARRA). These include the Ultra-High Sensitivity Aerosol Spectrometer (UHSAS), the Single-Particle Soot Photometer, and the Photo-Acoustic Soot Spectrometer. At the ground sites, a new Humidigraph, a Cloud Condensation Nuclei Counter, a Scanning Mobility Particle Sizer, and an upgraded $915-\mathrm{MHz}$ wind profiling radar will be deployed.

These measurements in the evolving urban plume will help constrain, evaluate, and improve detailed aerosol models that form the basis for developing and improving more efficient parameterizations suitable for use in regional and global aerosol/climate models.

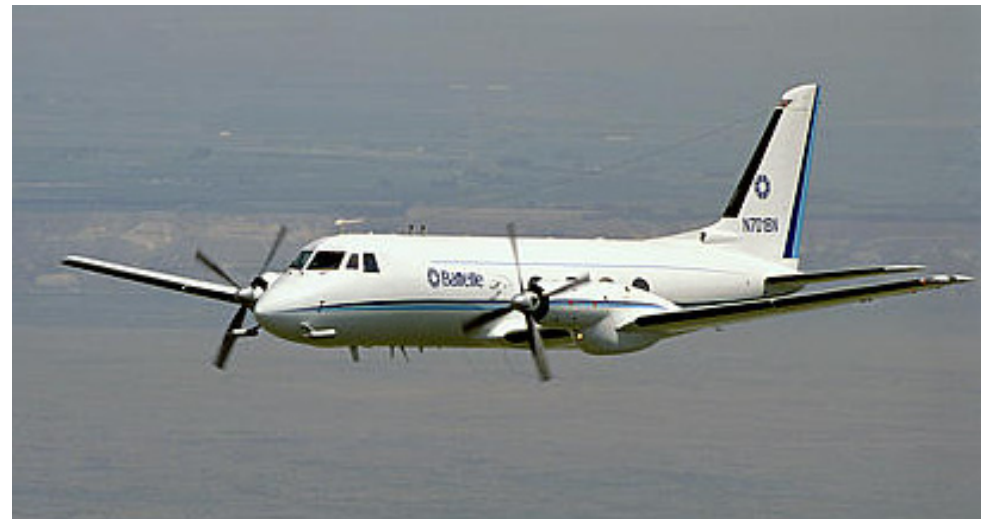

Figure 8. The DOE G-1 aircraft. 
Table 1. List of Planned Measurements and Instruments onboard the DOE G-1 Aircraft (Figure 8).

\begin{tabular}{|c|c|c|}
\hline Measurement & Instrument & PI \\
\hline \multicolumn{3}{|l|}{ Meteorology } \\
\hline Temperature & Rosemount 102 & Hubbe (PNNL) \\
\hline Dewpoint temperature & $\begin{array}{l}\text { General Eastern 1011B chilled-mirror } \\
\text { hygrometer }\end{array}$ & Hubbe (PNNL) \\
\hline Absolute humidity & Maycomm Tunable Diode Laser & Hubbe (PNNL) \\
\hline Static pressure & Rosemount 1201F1 & Hubbe (PNNL) \\
\hline Gust probe & Rosemount $1221 \mathrm{~F} 2$ & Hubbe (PNNL) \\
\hline \multicolumn{3}{|l|}{ Trace Gases } \\
\hline $\mathrm{CO}$ & Resonance Limited VUV-Fluorescence & Springston (BNL) \\
\hline $\mathrm{SO}_{2}$ & TEI 43S & Springston (BNL) \\
\hline $\mathrm{O}_{3}$ & TEI 49-100 & Springston (BNL) \\
\hline $\mathrm{NO}, \mathrm{NO}_{2}$, and $\mathrm{NO}_{\mathrm{y}}$ & Research Grade Instruments & Springston (BNL) \\
\hline Hydrocarbon trace gases & PTR-MS & Shilling (PNNL) \\
\hline \multicolumn{3}{|l|}{ Aerosol Size } \\
\hline Number conc. $>3 \mathrm{~nm}$ & TSI-3025 CPC & Comstock/Tomlinson (PNNL) \\
\hline Number conc. > $10 \mathrm{~nm}$ & TSI-3010 CPC & Comstock/Tomlinson (PNNL) \\
\hline PSD: $20-70 \mathrm{~nm}$ & FIMS & Wang (BNL) \\
\hline PSD: 55-1000 nm & UHSAS & Comstock/Tomlinson (PNNL) \\
\hline PSD: 500-20000 nm & CAPS/CAS & Senum (BNL) \\
\hline \multicolumn{3}{|l|}{ Aerosol Composition } \\
\hline Aerosol composition & HR-ToF-AMS (EMSL) & Shilling (PNNL) \\
\hline $\begin{array}{l}\text { Single particle composition and } \\
\text { size }\end{array}$ & ATOFMS & Prather (UCSD) \\
\hline Soot mass & SP2 & Sedlacek (BNL) \\
\hline $\begin{array}{l}\text { Water-soluble aerosol chemical } \\
\text { composition }\end{array}$ & PILS with autosampler & Brechtel (BMI) \\
\hline Aerosol chemical composition & TRAC Collector & Laskin (EMSL) \\
\hline \multicolumn{3}{|l|}{ Optical Properties } \\
\hline Aerosol light scattering & 3- $\lambda$ TSI 3563 Nephelometer & Hubbe (PNNL) \\
\hline Aerosol light absorption & $3-\lambda$ PSAP & Hubbe (PNNL) \\
\hline $\begin{array}{l}\text { Aerosol light absorption and } \\
\text { scattering }\end{array}$ & $3-\lambda \operatorname{PAS}(405,532,870 \mathrm{~nm})$ & Dubey (LANL) \\
\hline
\end{tabular}




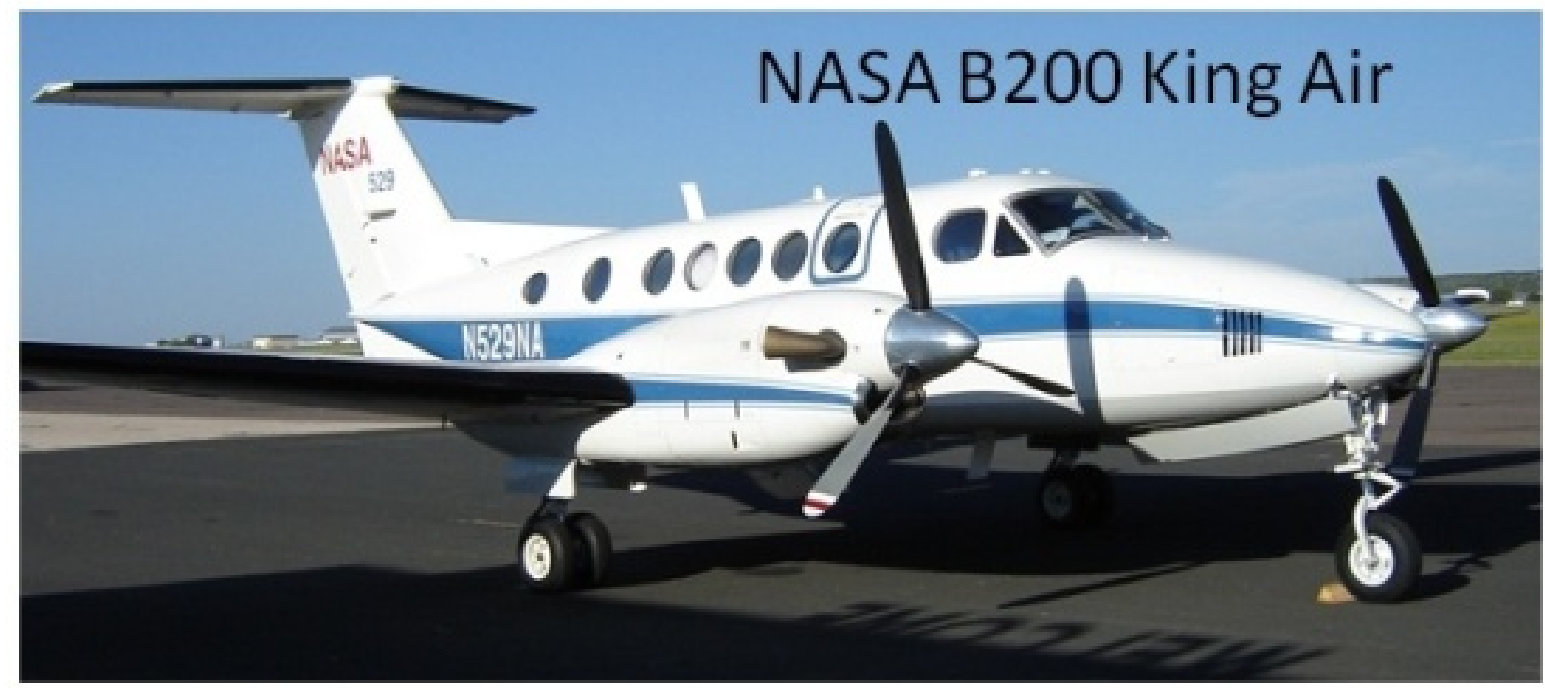

Figure 9. The NASA B200 King Air aircraft.

Table 2. List of Planned Measurements and Instruments onboard the NASA B-200King Air Aircraft (Figure 9).

\begin{tabular}{|l|l|l|}
\hline \multicolumn{1}{|c|}{ Measurement } & \multicolumn{1}{c|}{ Instrument } & PI \\
\hline Backscatter ratio $(532 \mathrm{~nm})$ & High Spectral Resolution Lidar & Ferrare/Hostetler (NASA \\
\hline Backscatter coefficient $(532$ and $1064 \mathrm{~nm})$ & High Spectral Resolution Lidar & Ferrare/Hostetler (NASA \\
\hline Extinction coefficient $(532 \mathrm{~nm})$ & High Spectral Resolution Lidar & Ferrare/Hostetler (NASA \\
\hline Depolarization & High Spectral Resolution Lidar & Ferrare/Hostetler (NASA \\
\hline Aerosol optical depth & Research Scanning Polarimeter & Cairns (NASA/GISS \\
\hline
\end{tabular}


Table 3. List of Planned Measurements and Instruments at T0.

\begin{tabular}{|c|c|c|}
\hline Measurement & Instrument & PI \\
\hline \multicolumn{3}{|l|}{ Meteorology } \\
\hline Wind profile & Wind Profiler & Berg (PNNL) \\
\hline Temperature, $\mathrm{RH}$ profile & Radiosonde & Berg (PNNL) \\
\hline Surface $T, P, R H$, wind & Vaisala WXT-510 & Jobson (WSU) \\
\hline \multicolumn{3}{|l|}{ Trace Gases (in WSU Shelter) } \\
\hline Hydrocarbon trace gases & PTR-MS & Jobson (WSU) \\
\hline Semi-volatile organic gases & GC-ITMS & Jobson (WSU) \\
\hline $\mathrm{CO}$ & Vacuum UV fluorescence & Jobson (WSU) \\
\hline $\mathrm{O}_{3}$ & UV absorption & Jobson (WSU) \\
\hline $\mathrm{NO}, \mathrm{NO}_{2}, \mathrm{NO}_{\mathrm{y}}$ & Research grade instruments & Jobson (WSU) \\
\hline $\mathrm{SO}_{2}$ & Thermo Model 43i & Song (PNNL) \\
\hline \multicolumn{3}{|l|}{ Aerosol Size } \\
\hline Size distribution & SMPS + CPC: $10 \mathrm{~nm}-1000 \mathrm{~nm}$ & Song (PNNL) \\
\hline Size distribution & APS: $500 \mathrm{~nm}-20000 \mathrm{~nm}$ & Jobson (WSU) \\
\hline \multicolumn{3}{|l|}{ Aerosol Composition } \\
\hline Composition and volatility & HR-ToF-AMS + thermal denuder & Song (PNNL) \\
\hline Aerosol atomizer & & Song (PNNL) \\
\hline Single particle composition & SPLAT II + SMPS & Zelenyuk (EMSL) \\
\hline Soot mass & SP2 (BNL) & Subramanian (DMT) \\
\hline Water-soluble aerosol species & PILS with autosampler & Zhang (UC Davis) \\
\hline Organic and elemental carbon & Sunset OC/EC & Laulainen (PNNL) \\
\hline Aerosol chemical composition & TRAC Collector & Laskin (EMSL), Gilles (LBNL) \\
\hline Aerosol chemical composition & DRUM Sampler & Laskin (EMSL) \\
\hline Aerosol morphology & SEM Collector & Mazzoleni (MTU) \\
\hline Offline Cl-ToF-AMS & Hi-vol Filter & Thornton (UW) \\
\hline Aldehydes and polar organics & Hi-vol Filter & Kubatova (UND) \\
\hline \multicolumn{3}{|c|}{ Radiation and Aerosol Optical Properties } \\
\hline $\mathrm{J}-\mathrm{NO}_{2}$ & $4 \pi \mathrm{J}-\mathrm{NO} 2$ radiometer & Laulainen (PNNL) \\
\hline Broadband solar radiation flux & Pyranometer & Berg (PNNL) \\
\hline $\begin{array}{l}\text { Direct normal and diffuse } \\
\text { horizontal and total horizontal solar } \\
\text { irradiances }\end{array}$ & MFRSR & Berg (PNNL) \\
\hline Light scattering & Nephelometer & Pekour (PNNL) \\
\hline Light absorption & PSAP & Pekour (PNNL) \\
\hline Light absorption and scattering & PAS-2 (405, 870), PA-1047 nm & Arnott (UNR) \\
\hline Light absorption and scattering & $\begin{array}{l}\text { PAS-3 }(405,532,870 \mathrm{~nm})+\text { thermal } \\
\text { denuder }\end{array}$ & Dubey (LANL) \\
\hline Light absorption and scattering & PAS-3 $(405,532,870 \mathrm{~nm})$, PA-375 nm & Dubey (LANL) \\
\hline Light extinction and scattering & $\operatorname{CRD}(355,532,1064 \mathrm{~nm})$ & Atkinson (PSU) \\
\hline \multicolumn{3}{|l|}{ Hygroscopic and CCN Properties } \\
\hline Cloud condensation nuclei & CCN Counter & Cziczo (PNNL) \\
\hline Hygroscopic growth & Humidigraph - $f(R H)$ & Cziczo (PNNL) \\
\hline
\end{tabular}


Table 4. List of Planned Measurements and Instruments at T1.

\begin{tabular}{|c|c|c|}
\hline Measurement & Instrument & PI \\
\hline \multicolumn{3}{|l|}{ Meteorology } \\
\hline Wind profile & Sodar & Berg (PNNL) \\
\hline Temperature, $\mathrm{RH}$ profile & Radiosonde & Berg (PNNL) \\
\hline Surface $T, P, R H$, wind & Met Station & Berg (PNNL) \\
\hline \multicolumn{3}{|l|}{ Trace Gases } \\
\hline Hydrocarbon trace gases & PTR-MS & Knighton (MSU) \\
\hline $\mathrm{CO}$ & Teledyne Model 300 U CO Analyzer & Dubey (LANL) \\
\hline $\mathrm{CO}_{2}-\mathrm{CH}_{4}-\mathrm{H}_{2} \mathrm{O}$ & Picarro Cavity Ringdown Analyzer & Dubey (LANL) \\
\hline O3 (PNNL) & Chen Song will calibrate instrument & Dubey (LANL) \\
\hline $\mathrm{NO}, \mathrm{NO}_{\mathrm{y}}$ & Research grade instruments & Dubey (LANL) \\
\hline \multicolumn{3}{|l|}{ Aerosol Size } \\
\hline Size distribution & SMPS: 10 nm - 1000 nm & Onasch (Aerodyne) \\
\hline Size distribution & APS: $500 \mathrm{~nm}-20000 \mathrm{~nm}$ & Pekour (PNNL) \\
\hline \multicolumn{3}{|l|}{ Aerosol Composition } \\
\hline Composition and volatility & HR-ToF-AMS + thermal denuder & Onasch (Aerodyne) \\
\hline Single particle composition & PALMS & Cziczo (PNNL) \\
\hline Soot mass & SP2 & Subramanian (DMT) \\
\hline Water-soluble aerosol species & PILS with autosampler & Zhang (UC Davis) \\
\hline Organic and elemental carbon & Sunset OC/EC & Laulainen (PNNL) \\
\hline Aerosol chemical composition & TRAC & Laskin (EMSL), Gilles (LBNL) \\
\hline Aerosol chemical composition & DRUM Sampler & Laskin (EMSL) \\
\hline Aerosol morphology & SEM Collector & Mazzoleni (MTU) \\
\hline Aldehydes and polar organics & Hi-vol Filter & Kubatova (UND) \\
\hline Radiocarbon & Hi-vol Filter & Gaffney (U Ark) \\
\hline Dissolved organics in rainwater & Wet/Dry Collector for precip. & Gaffney (U Ark) \\
\hline \multicolumn{3}{|c|}{ Radiation and Aerosol Optical Properties } \\
\hline Actinic flux & Diode-Array Spectroradiometer & Laulainen (PNNL) \\
\hline Broadband solar radiation flux & Pyranometer & Barnard (PNNL) \\
\hline $\begin{array}{l}\text { Direct normal and diffuse } \\
\text { horizontal and total horizontal } \\
\text { solar irradiances }\end{array}$ & MFRSR & Pekour (PNNL) \\
\hline Light scattering & Nephelometer & Pekour (PNNL) \\
\hline Light absorption & Athelometer & Sedlacek (BNL) \\
\hline Light absorption & PSAP & Pekour (PNNL) \\
\hline Light absorption and scattering & PA-355, PA-532, PA-870 & Arnott (UNR) \\
\hline Light absorption and scattering & $\begin{array}{l}\text { PAS-3 }(405,532,870 \mathrm{~nm}), \text { PA-375 } \mathrm{nm}+ \\
\text { thermal denuder }\end{array}$ & Dubey (LANL) \\
\hline Light extinction and scattering & $\operatorname{CRD}(355,532,1064 \mathrm{~nm})$ & Atkinson (PSU) \\
\hline \multicolumn{3}{|l|}{ Hygroscopic \& CCN Properties } \\
\hline Cloud condensation nuclei & CCN Counter & Cziczo (PNNL) \\
\hline Hygroscopic growth & Humidigraph - $f(R H)$ & Cziczo (PNNL) \\
\hline Size-selected CCN & SCCN Counter & Wang (BNL) \\
\hline
\end{tabular}




\subsection{Sample Flight Plans}

\section{Morning 1: 9:00 am-12:00 pm (or 10:00 am-1:00 pm)}

The flight plan shown below is designed to sample the freshly emitted aerosols and their precursor gases in the Sacramento urban area in the morning. The G-1 aircraft will sample within, outside, and upwind of the urban area to characterize the location and extent of the urban plume. Legs passing over the T1 site along the Sierra Nevada foothills will be performed toward the end of the flight to sample biogenic emissions from the forested areas. The B-200 aircraft will follow a similar flight pattern at 28,000 feet to characterize the vertical distribution of aerosols and provide guidance to the G-1 in real time.
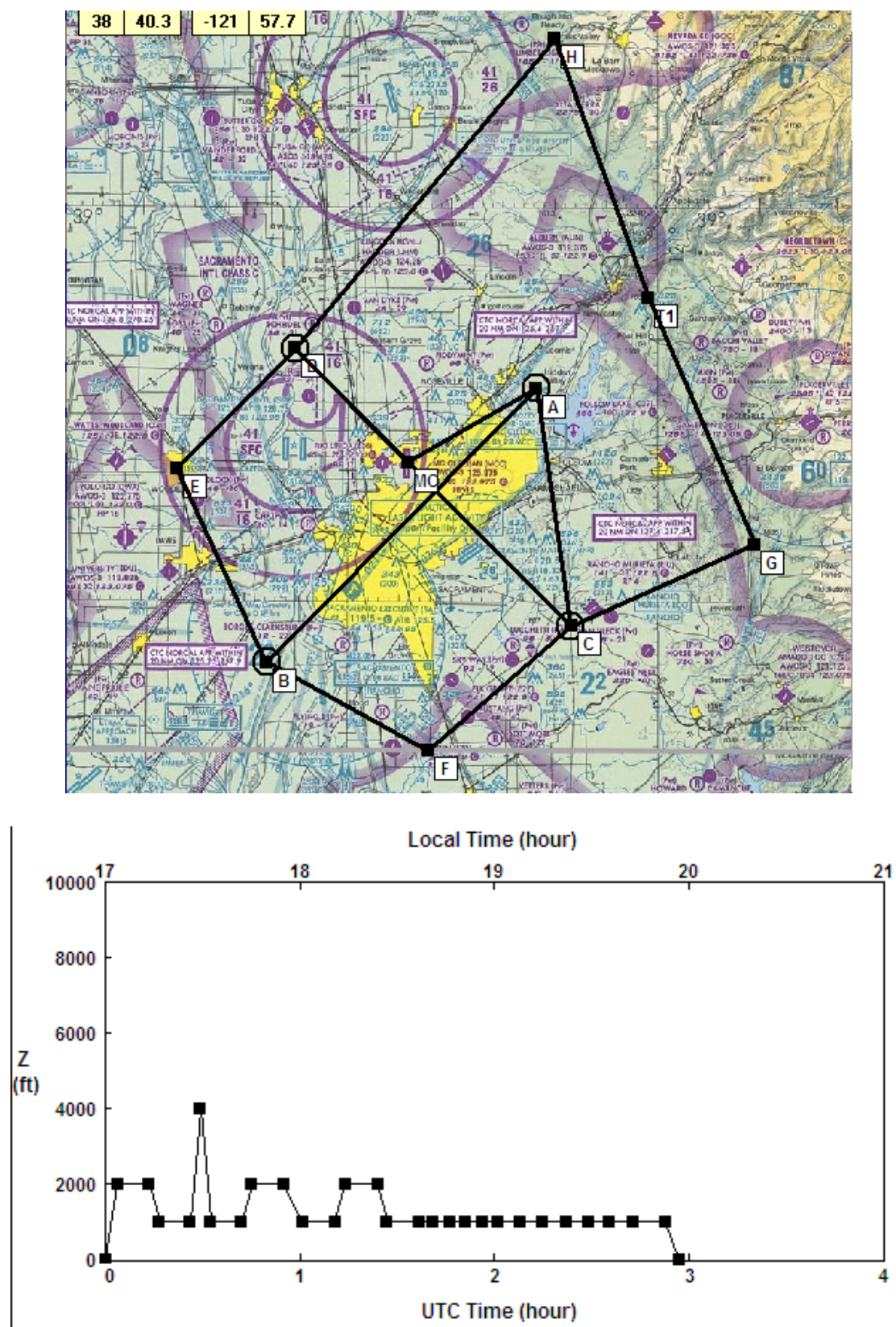

Figure 10. "Morning 1" Flight Plan. 


\section{Morning 2: 9:00 am-12:30 pm (or 10:00 am-1:30 pm)}

The "Morning 2" flight plan shown below will be considered when the Bay Area emissions are forecasted to reach Sacramento area by afternoon. This plan is designed to sample the freshly emitted aerosols and their precursor gases just downwind from the Bay Area, with a leg just upwind of Sacramento area towards the end of the flight. The B-200 aircraft will follow a similar flight pattern at 28,000 feet to characterize the vertical distribution of aerosols and provide guidance to the G-1 in real time.
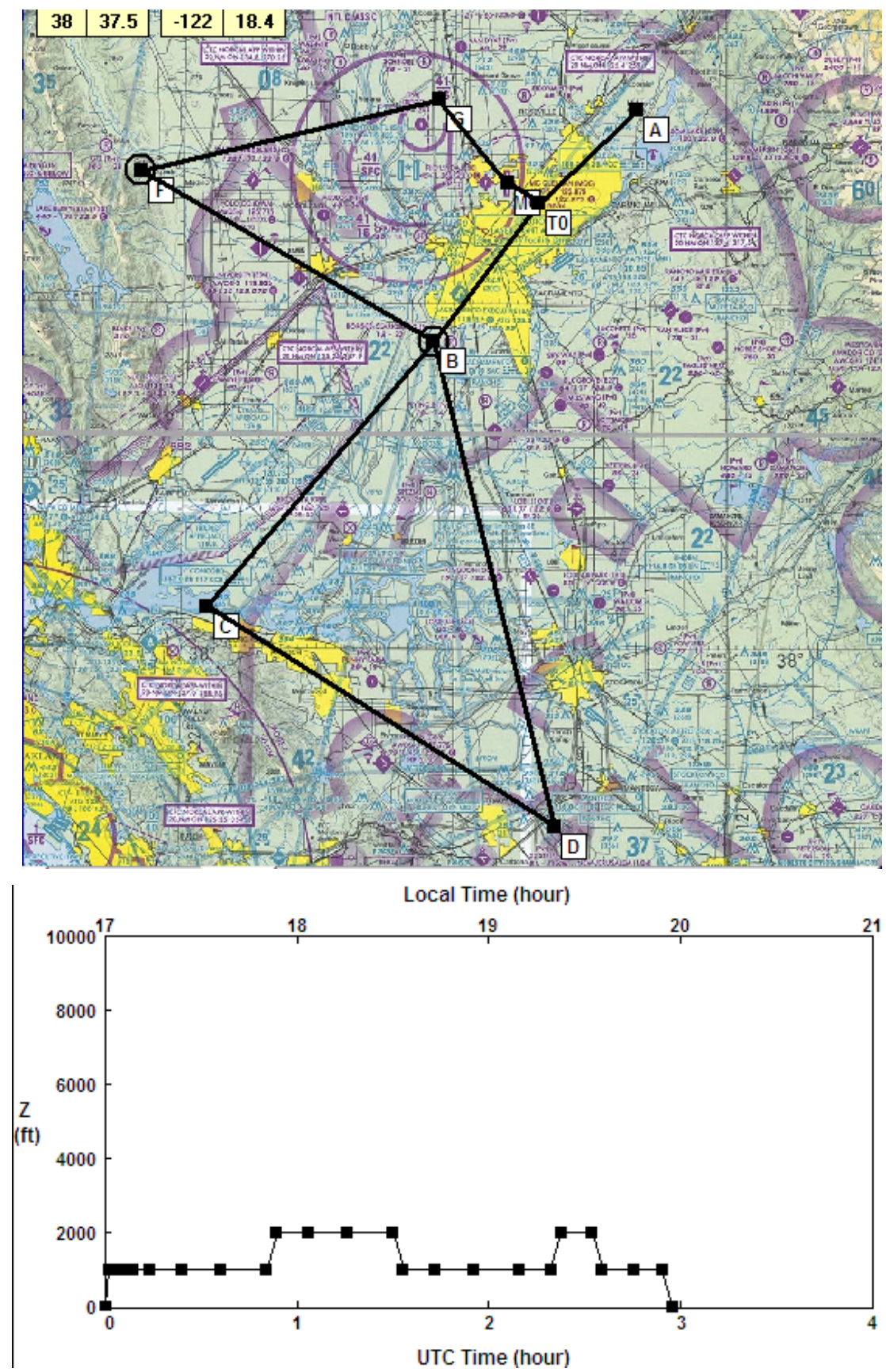

Figure 11. "Morning 2" Flight Plan. 


\section{Afternoon 1: 3:00 pm-6:30 pm (or 4:00 pm-7:30 pm)}

The "Afternoon 1" flight plan shown below will be considered when the Sacramento and Bay Area morning plumes are forecasted to move to the northeast by afternoon. This plan is designed to sample the aged aerosols and their precursor gases, with a leg over the mountains to characterize the mountain venting process. The B-200 aircraft will follow a similar flight pattern at 28,000 feet to characterize the vertical distribution of aerosols and provide guidance to the G-1 in real time.
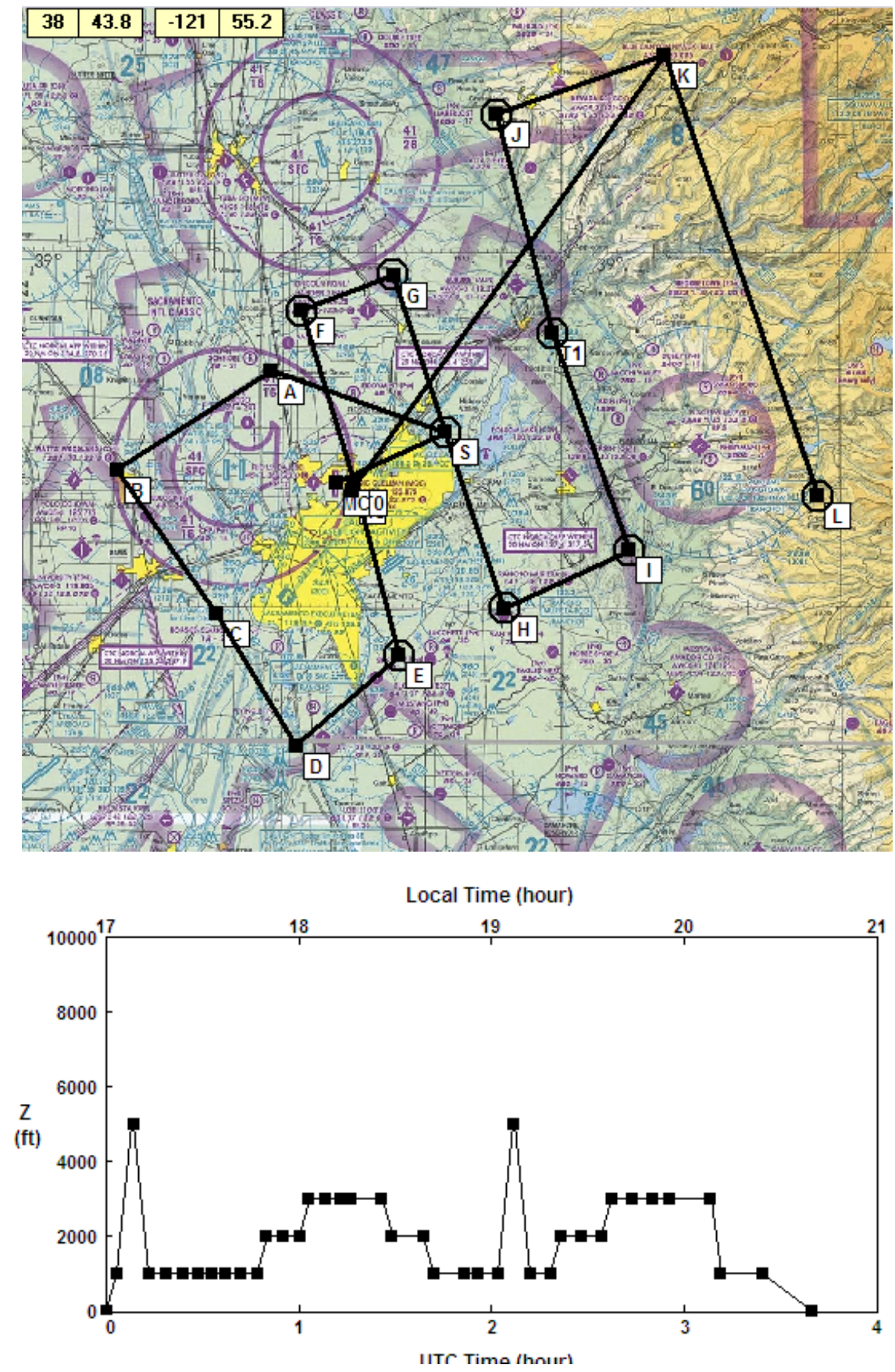

Figure 12. "Afternoon 1" Flight Plan. 


\section{Afternoon 2: 3:00 pm-6:30 pm (or 4:00 pm-7:30 pm)}

The "Afternoon 2" flight plan shown below will be considered when the Sacramento plume is forecasted to move southward in the afternoon. This plan is also designed to sample the aged aerosols, with a leg just upwind of Sacramento area at the beginning of the flight. The B-200 aircraft will follow a similar flight pattern at 28,000 feet to characterize the vertical distribution of aerosols and provide guidance to the G-1 in real time.
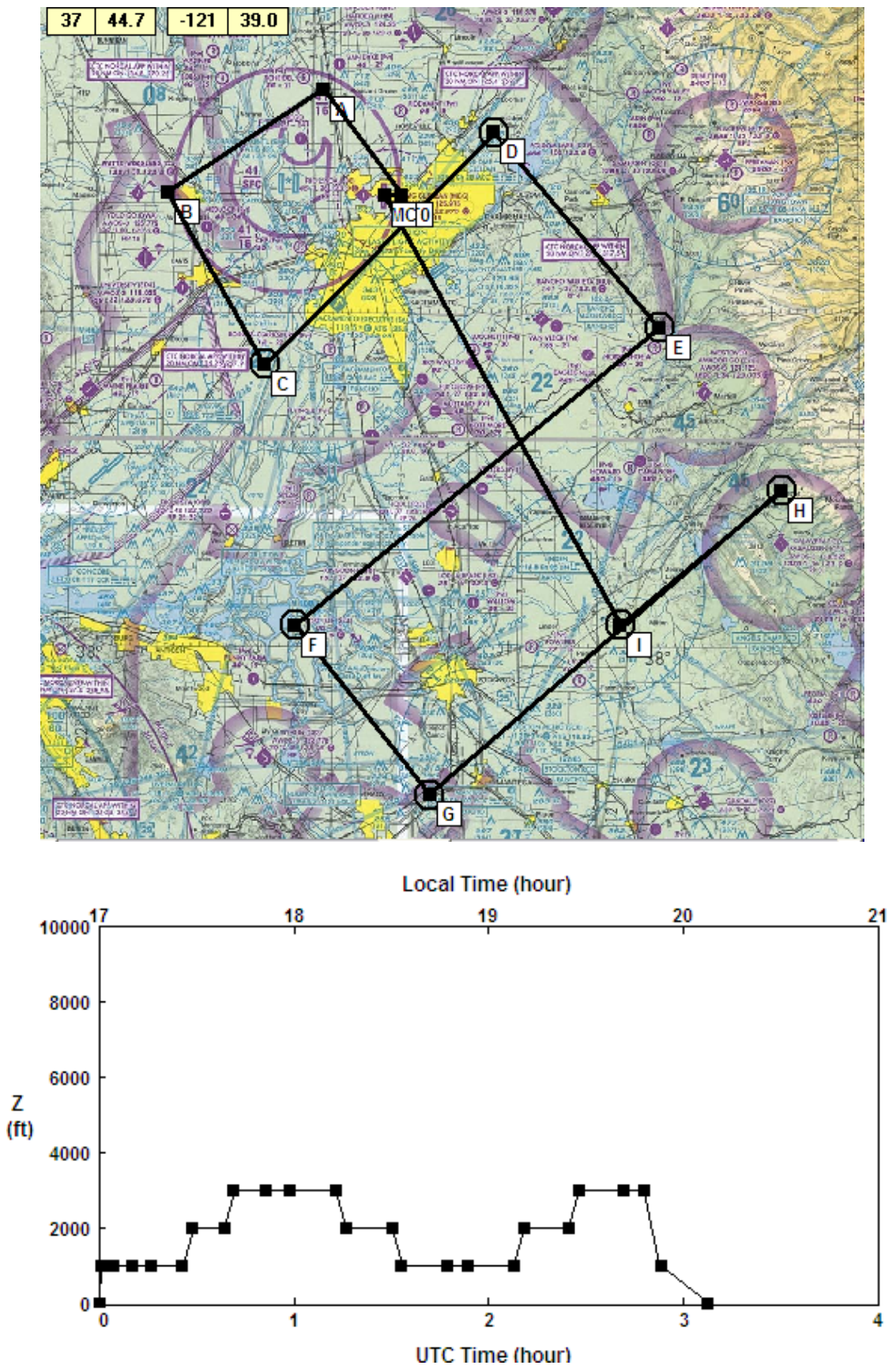

Figure 13. “Afternoon 2" Flight Plan. 


\section{Coordination with CalNex (NOAA P-3 and Twin Otter Aircraft and R/V Atlantis)}

An important advantage in selecting Sacramento for the 2010 DOE field campaign is the unique opportunity for ASR scientists to collaborate with investigators from the National Oceanic and Atmospheric Administration (NOAA) and the California Air Resources Board (CARB), who are also planning a major field study, CalNex 2010, in the Central Valley and Southern California regions in May and June 2010. The CalNex study will focus on the atmospheric chemistry and meteorological processes that affect air quality and climate change issues both nationally and in the California region. NOAA will be deploying their richly instrumented P-3 aircraft from May 1 through June 23 during CalNex 2010. It will be based in Ontario, California, and will be able to sample up to 700 nautical miles from the base of operation. During the overlapping period with CARES, and as opportunity allows, one or more NOAA P3 aircraft flights will be carried out in the Sacramento plume in coordination with the G-1 flights. An informal wing-tip to wing-tip intercomparison flight will also be scheduled as early as June 6 or 7 in the Central Valley. Such exercises have benefitted both parties in the past, and it would be worthwhile to continue at every opportunity. Other P-3 flights throughout California will provide a regional context and boundary conditions for the CARES domain.

Additionally, the NOAA Twin Otter operation will move from Ontario to Sacramento (McClellan Airfield) from June 14-28. It will investigate the 3D distribution and transport processes of ozone and aerosols in the Central Valley using a combination of downward-looking ozone and Doppler wind lidars. Some of the processes they plan to study include the transport of pollutants from the Bay area into the Central Valley, the role of mountain slope flows in ventilating the Central Valley, and the distribution of mixing heights. During the overlapping period, and as opportunity allows, we will coordinate the G-1 and Twin Otter flights to enhance the synergism between the two platforms.

Another opportunity of collaboration will be with the NOAA Research Vessel Atlantis during the first week of June when they plan to sail up the Sacramento River. During this period, and as opportunity allows, we will carry out one or more G-1 flights over R/V Atlantis.

\section{Coordination with Satellite Overpasses}

When possible, we will coordinate the G-1 and NASA B-200 aircraft flights with the scheduled

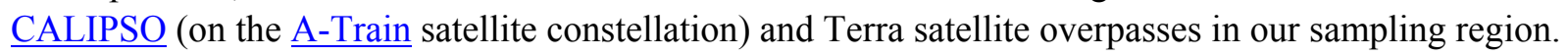
The CALIPSO payload consists of the Cloud-Aerosol Lidar with Orthogonal Polarization (CALIOP), which is a two-wavelength polarization-sensitive lidar that provides high-resolution vertical profiles of aerosols and clouds. The Multi-angle Imaging SpectroRadiometer (MISR) on the Terra satellite provides aerosol data products that include tropospheric aerosol optical depth, aerosol composition and size, and other related parameters.

\subsection{Measurements to Models}

Ghan and Schwartz (2007) recently outlined the DOE strategy for improving representation of the properties, processes, and effects of tropospheric aerosols in global climate models, which begins with a foundation in field and laboratory measurements that provide the basis for modules describing specific aerosol properties and processes. The CARES 2010 field campaign is designed with this strategy in mind. Using DOE support, PI Zaveri and colleagues at PNNL have developed a comprehensive and 
computationally efficient Model for Simulating Aerosol Interactions and Chemistry (MOSAIC), which treats new particle formation, aerosol thermodynamics, dynamic gas-particle mass transfer, heterogeneous chemistry, coagulation, and other microphysical calculations coupled with trace gas photochemistry (Zaveri and Peters 1999; Zaveri et al. 2005a, b, 2008). MOSAIC is coupled to the shell-core Mie code (Ackerman and Toon, 1981) to predict optical properties of aerosols as a function of particle size and composition, and it also includes the single-parameter $\kappa$-Kohler hygroscopicity module (Petters and Kreidenweis 2007) to predict the CCN activity as a function of particle size and composition. MOSAIC has been implemented in the chemistry version of the Weather Research and Forecasting model, WRFChem, a 3D model that simulates important climate feedback processes between aerosols, clouds, and radiation simultaneously with changes in meteorology (Fast et al. 2006, Gustafson et al. 2007). More recently, MOSAIC was coupled with a stochastic particle coagulation model, PartMC, to produce a stochastic particle-resolved aerosol model (PartMC-MOSAIC), which explicitly resolves the mixing state of individual particles in a given population of different types of aerosol particles (Riemer et al. 2008; Zaveri et al. 2010b). In the near future, we plan to incorporate a comprehensive treatment for SOA formation in MOSAIC in collaboration with Dr. Sasha Madronich (NCAR) and colleagues. A reduced version of MOSAIC is also planned for inclusion in the global climate model CAM5.

MOSAIC, PartMC-MOSAIC, and WRF-Chem/MOSAIC thus represent a set of comprehensive modeling tools that we plan to use in the interpretation and evaluation of the CARES field campaign data. We will carry out a number of studies to test and evaluate different aerosol processes and properties represented in MOSAIC:

(1) The extensive aircraft and ground-based trace gases, aerosol size, composition, mixing state, hygroscopicity, and optical properties data will be used to carry out local closure studies for optical properties and $\mathrm{CCN}$ activity.

(2) These measurements will also be suitable for constrained Lagrangian-box model analyses of SOA formation and size-distribution/BC mixing state evolution in the Sacramento plume using the MOSAIC (with a detailed SOA treatment) and PartMC-MOSAIC models.

(3) WRF-Chem/MOSAIC simulations with a grid spacing of $\sim 2 \mathrm{~km}$ will be able to resolve the meteorological processes responsible for vertical and horizontal gradients in trace gases and aerosols and provide a more complete 3D picture of the evolving Sacramento plume, which will be evaluated against the G-1 and ground-based measurements.

\subsection{References}

Ackerman, TP, and OB Toon. 1981. "Absorption of visible radiation in atmospheres containing mixtures of absorbing and nonabsorbing particles." Applied Optics 20: 3661-3668.

Barnard, JC, R Volkamer, and EI Kassianov. 2008. "Estimation of the mass absorption cross section of the organic carbon component of aerosols in the Mexico City Metropolitan Area (MCMA)." Atmospheric Chemistry and Physics Discussions 8: 10,189-10,225.

Bao, J-W, SA Michelson, POG Persson, IV Djalalova, and JM Wilczak. 2008. "Observed and WRFsimulated low-level winds in a high-ozone episode during the Central California Ozone Study." Journal of Applied Meteorology and Climatology 47: 2372-2394. 
Bergstrom, RW, PB Russell, and P Hignett. 2002. "Wavelength dependence of absorption of black carbon particles: Predictions and results from the TARFOX experiment and implications for the aerosol single scattering albedo." Journal of Atmospheric Science 59: 567-577.

Bond, TC, and RW Bergstrom. 2006. "Light absorption by carbonaceous particles: An investigative review." Aerosol Science and Technology 40, 27-67.

Clarke, A, C McNaughton, V Kapustin, Y Shinozuka, S Howell, J Dibb, J Zhou, B Anderson, V Brekhovskikh, H Turner, and M Pinkerton. 2007. " Biomass burning and pollution aerosol over North America: Organic components and their influence on spectral optical properties and humidification response.” Journal of Geophysical Research 112: D12S18, doi:10.1029/2006JD007777.

Chung, SH and JH Seinfeld. 2002. "Global distribution and climate forcing of carbonaceous aerosols." Journal of Geophysical Research 107(D19): 4407, doi:10.1029/2001JD001397.

de Gouw, JA, et al. 2005. "The budget of organic carbon in a polluted atmosphere: Results from the New England Air Quality Study in 2002." Journal of Geophysical Research 110: D16305, doi:10.1029/2004JD005623.

de Gouw, JA, et al. 2008. "Sources of particulate matter in the northeastern United States in summer: 1. Direct emissions and secondary formation of organic matter in urban plumes." Journal of Geophysical Research 113: D08301, doi:10.1029/2007JD009243.

de Gouw, JA, D Welsh-Bon, C Warneke, WC Kuster, ML Alexander, AK Baker, AJ Beyersdorf, DR Blake, M Canagaratna, LG Huey, TB Onasch, J Schauer, E Stone, AP Sullivan, O Vargas, RJ Weber, D R. Worsnop, X-Y Yu, and R Zaveri. 2009. "Emission and chemistry of organic carbon in the gas and aerosol phase at a suburban site near Mexico City in March 2006 during the MILAGRO study." Atmospheric Chemistry and Physics 9: 3425-3442.

Dillon, MB, MS Lamanna, GW Schade, AH Goldstein, and RC Cohen. 2002. "Chemical evolution of the Sacramento urban plume: Transport and oxidation." Journal of Geophysical Research 107: 4045, doi:10.1029/2001JD000969.

Donahue, NM, AL Robinson, CO Stanier, and SN Pandis. 2006. "Coupled partitioning, dilution, and chemical aging of semivolatile organics." Environmental Science and Technology 40: 2635-2643.

Fassi-Fihri, A, K Suhre, and R Rosset. 1997. "Internal and external mixing in atmospheric aerosols by coagulation: Impact on the optical and hygroscopic properties of the sulphate-soot system."

Atmospheric Environment 31: 1393-1402.

Fast, JD, WI Gustafson Jr, RC Easter, RA Zaveri, JC Barnard, EG Chapman, GA Grell, and SE Peckham. 2006. "Evolution of ozone, particulates, and aerosol direct radiative forcing in the vicinity of Houston using a fully coupled meteorology-chemistry-aerosol model." Journal of Geophysical Research 111: D21305, doi:10.1029/2005JD006721.

Ghan, SJ and SE Schwartz. 2007. "Aerosol properties and processes: A path from field and laboratory measurements to global climate models.” Bulletin of the Americal Meteorological Society 88: 10591083. 
Gustafson Jr, WI, EG Chapman, SJ Ghan, and JD Fast. 2007. "Impact on modeled cloud characteristics due to simplified treatment of uniform cloud condensation nuclei during NEAQS 2004." Geophysical Research Letters 34: L19809.

Heald, CL, et al. 2005. "A large organic aerosol source in the free troposphere missing from current models." Geophysical Research Letters 32: L18809, doi:10.1029/2005GL023831.

Herndon, SC, et al. 2008. "Correlation of secondary organic aerosol with odd oxygen in Mexico City." Geophysical Research Letters 35: L15804, doi:10.1029/2008GL034058.

Hughes, LS, JO Allen, P Bhave, MJ Kleeman, GR Cass, D-Y Liu, DP Fergensen, BD Morrical, and KA Prather. 2000. "Evolution of atmospheric particles along trajectories crossing the Los Angeles Basin." Environmental Science and Technology 34(15): 3058-3068.

Jacobson, MZ, et al. 1994. "Modeling coagulation among particles of different composition and size." Atmospheric Environment 28A: 1327-1338.

Jacobson, MZ. "Analysis of aerosol interactions with numerical techniques for solving coagulation, condensation, dissolution, and reversible chemistry among multiple size distributions." Journal of Geophysical Research 107: 4366, doi:10.1029/2001JD002044.

Jang, M, B Carroll, B Chandramouli, and RM Kamens. 2003. "Particle growth by acid-catalyzed heterogeneous reactions of organic carbonyls on preexisting aerosols." Environmental Science and Technology 37(17): 3828-3837.

Johnson, D, et al. 2006. "Simulating regional scale secondary organic aerosol formation during the TORCH 2003 campaign in the southern UK." Atmospheric Chemistry and Physics 6: 403-418.

Kanakidou, M, K Tsigaridis, FJ Dentener, and PJ Crutzen. 2000. "Human-activity-enhanced formation of organic aerosols by biogenic hydrocarbon oxidation." Journal of Geophysical Research 105: 92439254.

Kanakidou, M, et al. 2005. "Organic aerosol and global climate modelling: a review." Atmospheric Chemistry and Physics 5: 1053-1123.

Kirchstetter, TW, T Novakov, and P Hobbs. 2004. "Evidence that the spectral dependence of light absorption by aerosols is affected by organic carbon." Journal of Geophysical Research 109: D21208, doi:10.1029/2004JD004999.

Kleeman, MJ, et al. 1997. "Modeling the airborne particle complex as a source-oriented external mixture." Journal of Geophysical Research 102: 21,355-21,372.

Kleinman, LI, et al. 2008. "The time evolution of aerosol composition over the Mexico City plateau." Atmospheric Chemistry and Physics 8: 1559-1575.

Kroll, JH, NL Ng, SM Murphy, V Varutbangkul, RC Flagan, and JH Seinfeld. 2005. "Chamber studies of secondary organic aerosol growth by reactive uptake of simple carbonyl compounds." Journal of Geophysical Research 110: D23207, doi:10.1029/2005JD006004. 
Lack, DA, CD Cappa, T Baynard, P Massoli, DS Covert, B Sierau, TS Bates, PK Quinn, ER Lovejoy, and AR Ravishankara. 2008. "Bias in filter based aerosol absorption measurements due to organic aerosol loading: evidence from ambient sampling." Aerosol Science and Technology 42(12): 1033-1041.

Lewis, AC, M Carslaw, PJ Marriott, RM Kinghorn, P Morrison, AL Lee, KD Bartle, MJ Pilling. 2000. "A larger pool of ozone forming carbon compounds in urban atmospheres." Nature 405: 778-781.

Lewis, K, WP Arnott, H Moosmüller, and CE Wold. 2008. "Strong spectral variation of biomass smoke light absorption and single scattering albedo observed with a novel dual-wavelength photoacoustic instrument." Journal of Geophysical Research 113: D16203, doi:10.1029/2007JD009699.

Liggio, J, S-M Li, and R McLaren. 2005. "Reactive uptake of glyoxal by particulate matter." Journal of Geophysical Research 110: D10304, doi:10.1029/2004JD005113.

Liggio, J, S-M Li, JR Brook, and C Mihele. 2007. "Direct polymerization of isoprene and $\alpha$-pinene on acidic aerosols." Geophysical Research Letters 34: L05814, doi:10.1029/2006GL028468.

Limbeck, A, M Kulmala, and H Puxbaum. 2003. "Secondary organic aerosol formation in the atmosphere via heterogeneous reaction of gaseous isoprene on acidic particles." Geophysical Research Letters 30(19): 1996, doi:10.1029/2003GL017738.

Moffet, RC, and KA Prather. 2005. "Extending ATOFMS measurements to include refractive index and density." Analytical Chemistry 77(20): 6535-6541.

Moffet, RC, X Qin, T Rebotier, H Furutani, and KA Prather. 2008. "Chemically segregated optical and microphysical properties of ambient aerosols measured in a single-particle mass spectrometer." Journal of Geophysical Research 113: D12213, doi:10.1029/2007JD009393.

Murphy, DM, and DS Thomson. 1997. "Chemical composition of single aerosol particles at Idaho Hill: Negative ion measurements.” Journal of Geophysical Research 102(D5): 6353-6368.

Murphy, J, DA Day, PA Cleary, PJ Wooldridge, and RC Cohen. 2006. "Observations of the diurnal and seasonal trends in nitrogen oxides in the western Sierra Nevada." Atmospheric Chemistry and Physics 6: $5321-5338$.

Murphy, JG, DA Day, PA Cleary, PJ Wooldridge, DB Millet, AH Goldstein, and RC Cohen. 2007. "The weekend effect within and downwind of Sacramento - Part 1: Observations of ozone, nitrogen oxides, and VOC reactivity." Atmospheric Chemistry and Physics 7: 5327-5339.

Odum, JR, T Hoffmann, F Bowman, D Collins, RC Flagan, and JH Seinfeld. 1996. "Gas/particle partitioning and secondary organic aerosol yields." Environmental Science and Technology 30: 25802585.

Odum, JR, TPW Jungkamp, RJ Griffin, HJL Forstner, RC Flagan, and JH Seinfeld. 1997. “Aromatics, reformulated gasoline, and atmospheric organic aerosol formation." Environmental Science and Technology 31: 1890-1897. 
Petters, MD, and SM Kreidenweis. 2007. "A single parameter representation of hygroscopic growth and cloud condensation nucleus activity." Atmospheric Chemistry and Physics 7, 1961-1971.

Riemer, N, M West, RA Zaveri, and RC Easter. 2008. "Simulating the evolution of soot mixing state with a particle-resolved aerosol model." Journal of Geophysical Research, in review.

Robinson, AL, NM Donahue, MK Shrivastava, EA Weitkamp, AM Sage, AP Grieshop, TE Lane, JR Pierce, and SN Pandis. 2007. "Rethinking organic aerosols: semivolatile emissions and photochemical aging." Science 315: 1259-1262.

Seinfeld, JH, and SN Pandis. 1998. Atmospheric Chemistry and Physics, From Air Pollution to Climate Change. John Wiley, Hoboken, New Jersey.

Song, C, RA Zaveri, ML Alexander, JA Thornton, S Madronich, JV Ortega, A Zelenyuk, X-Y Yu, A Laskin, and D Maughan. 2007. "Effect of hydrophobic primary organic aerosol on secondary organic aerosol formation from ozonolysis of $\alpha$-pinene." Geophysical Research Letters 34: L20803, doi:10.1029/2007GL030720.

Spencer, MT, and KA Prather. 2006. "Using ATOFMS to determine OC/EC mass fractions in particles." Aerosol Science and Technology 40(8): 585-594.

Steiner, AL, RC Cohen, RA Harley, S Tonse, AH Goldstein, DB Millet, and GW Schade. 2007. "VOC reactivity in central California: comparing an air quality model to ground-based measurements." Atmospheric Chemistry and Physics Discussions 7: 13,077-13,119.

Strom, J, K Okada, and J Heintzenberg. 1992. "On the state of mixing of particles due to Brownian coagulation." Journal of Aerosol Science 23: 467-480.

Sun, H, L Biedermann, and TC Bond. 2007. "The color of brown carbon: A model for ultraviolet and visible light absorption by organic carbon aerosol." Geophysical Research Letters 34: L17813, doi:10.1029/2007GL029797.

Tsigaridis, K, et al. 2006. "Change in global aerosol composition since preindustrial times." Atmospheric Chemistry and Physics 6: 5143-5162.

Volkamer, R, et al. 2006. "Secondary organic aerosol formation from anthropogenic air pollution: Rapid and higher than expected." Geophysical Research Letters 33: doi:10.1029/2006GL026899.

Weber, RJ, et al. 2007. "A study of secondary organic aerosol formation in the anthropogenic-influenced southeastern United States." Journal of Geophysical Research 112: D13302, doi:10.1029/2007JD008408.

Wexler, AS, and JH Seinfeld. 1991. "Second-generation inorganic aerosol model." Atmospheric Environment 25A: 2731-2748.

Zaveri, RA and LK Peters. 1999. "A new lumped structure photochemical mechanism for large-scale applications." Journal of Geophysical Research 104: 30,387-30,415. 
Zaveri, RA, RC Easter, and LK Peters. 2005a. "A computationally efficient Multicomponent Equilibrium Solver for Aerosols (MESA).” Journal of Geophysical Research 110: D24203, doi:10.1029/2004JD005618.

Zaveri, RA, RC Easter, and AS Wexler. 2005b. "A new method for multicomponent activity coefficients of electrolytes in aqueous atmospheric aerosols." Journal of Geophysical Research 110: D02201, doi:10.1029/2004JD004681.

Zaveri, RA, RC Easter, JD Fast, and LK Peters. 2008. "Model for Simulating Aerosol Interactions and Chemistry (MOSAIC)." Journal of Geophysical Research 113: D13204, doi:10.1029/2007JD008782,.

Zaveri, RA, C Song, ML Alexander, Y Xie, X-Y Yu, J de Gouw, D Welsh-bon, C Warneke, M Canagaratna, TB Onasch, JT Jayne, DR Worsnop, and G Huey. 2010a. "Unraveling the contributions of urban, biomass burning, and secondary organic aerosols near Mexico City during the MILAGRO 2006 Study." In preparation.

Zaveri, RA, JC Barnard, RC Easter, N Riemer, and M West. 2010b. "Particle-resolved simulation of aerosol size, composition, mixing state, and the associated optical and cloud condensation nuclei activation properties in an evolving urban plume." Journal of Geophysical Research: doi:10.1029/2009JD013616, in press.

Zelenyuk, A, Y Cai, and D Imre, 2006. "From agglomerates of spheres to irregularly shaped particles: Determination of dynamic shape factors from measurements of mobility and vacuum aerodynamic diameters." Aerosol Science and Technology 40: 197-217.

Zhang, Q, et al. 2007. "Ubiquity and dominance of oxygenated species in organic aerosols in anthropogenically-influenced northern hemisphere mid-latitudes." Geophysical Research Letters 34: L13801.

Zhang, Y, B Pun, K Vijayaraghavan, S-Y Wu, C Seigneur, SN Pandis, MZ Jacobson, A Nenes, and JH Seinfeld. 2004. "Development and application of the Model of Aerosol Dynamics, Reaction, Ionization, and Dissolution (MADRID)." Journal of Geophysical Research 109: D01202, doi:10.1029/2003JD003501. 


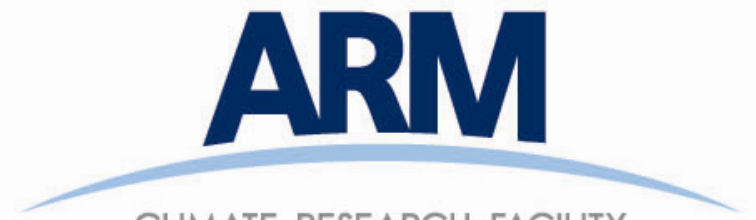

CLIMATE RESEARCH FACILITY

www.arm.gov
U.S. DEPARTMENT OF

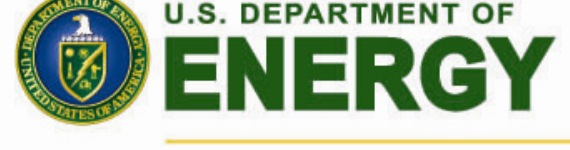

Office of Science 